\title{
Badenska kultura
}

\author{
The Baden culture
}

\author{
Jacqueline Balen \\ Arheološki muzej u Zagrebu \\ Archeological museum in Zagreb \\ jbalen@amz.hr
}

DOI: $10.17234 / 9789531758185-05$

Badenska kultura vrlo je raširena kulturna pojava po panonsko-podunavskom području; obuhvaća prostor Austrije, Moravske, Češke, južne Slovačke, dijela južne Poljske, Mađarske, Vojvodine i sjeverne Srbije i sjeveroistočnu Hrvatsku.

Opći položaj badenske kulture odredio je Milojčić 1949. godine na osnovi stratigrafije Vinče, Bapske i Sarvaša, po čemu je kultura determinirana kao nasljednica vinčanske kulture, odnosno kao prva eneolitička kultura. Određeni zaokret postignut je šezdesetih godina 20. st. kada su J. Banner i I. Bognar-Kutzián izveli tezu o proritetu tiszapolgarske i bodrogkeresztúrske kulture nad badenskom (1961). lako je ovo stajalište uglavnom odmah podržano u europskim znanstvenim krugovima, mišljenje S. Dimitrijevića i dalje je bilo da badenska kultura predstavlja ranoeneolitičku pojavu te da je ona glavni nositelj kulturne smjene kamenoga u bakreno doba (Dimitrijević 1979: 188-191), što je neko vrijeme podržavao i Z. Marković (1977: 48). Danas možemo zaključiti da badenskom kulturom ne počinje razdoblje eneolitika u ovim prostorima, iako je njezinim dolaskom došlo do korjenitih promjena u društvenoj organizaciji kao i u gospodarskoj orijentaciji.

Značajni rezultati u istraživanju badenske kulture u posljednje su vrijeme postignuti na prostoru Mađarske i Češke, dok u odnosu na njih, rezultati temeljeni na istraživanju badenskih nalazišta $i$ na izučavanju badenske kulture nisu na prostoru
The Baden culture is a widespread cultural occurrence that spans across the entire Pannonia-Danube territory, including the area of Austria, Moravia, the Czech Republic, southern Slovakia, parts of southern Poland, Hungary, Vojvodina and northern Serbia, and northeastern Croatia.

The general position of the Baden culture was defined by Milojčić in 1949 based on the stratigraphy of Vinča, Bapska and Sarvaš. The culture was defined as the successor of the Vinča culture, i.e. as the first Eneolithic culture. Certain changes occurred during the 1960s, when J. Banner and I. Bognar-Kutzián proposed that the Tiszapolgár and Bordrogkeresztúr cultures were antecedents of the Baden culture (1961). Although this viewpoint was mostly supported in European scientific circles, $\mathrm{S}$. Dimitrijević still thought that the Baden culture was an Early Eneolithic occurrence and that it was the main representative of the transition from the Stone into the Copper Age (Dimitrijević 1979: 188191), a hypothesis that was, for a while, also supported by Z. Marković (1977: 48). Today, it can be concluded that the Baden culture did not mark the start of the Eneolithic in these regions, although its emergence introduced radical changes in both social organization and economic orientation.

Lately, significant results in the research of the Baden culture have been obtained in Hungary and the Czech Republic. On the other hand, results based on excavations and research into the Baden 
Hrvatske adekvatno brojni i značajni u odnosu na broj poznatih nalazišta te kulture (Marković 1994: 222, karta 12), što uvelike utječe i na nemogućnost stvaranja opće slike o toj kulturnoj pojavi.

Širi pak interes za problematiku badenske kulture nalazi se u radovima S. Dimitrijevića. Njegov rad u Arheološkim radovima i raspravama (Dimitrijević 1962) prvi je pokušaj da se badenski materijal s prostora Hrvatske (iako je obrađena građa i iz Vojvodine) klasificira i izvrši periodizacija. N. Tasić također se uvelike dotakao problema badenske kulture s hrvatskih nalazišta (1967). lako u osnovi sa značajnim nedostacima djelo R. R.Schmidta (1945) važno je kao prvi pokušaj da se materijal s prostora Hrvatske prikupi i sagleda u okviru samostalne kulture.

Za prostor Hrvatske još uvijek je u literaturi uobičajeno mišljenje da je ona periferna pojava kratkog trajanja, bez obzira na veliki broj nalazišta na kojima je ustanovljena (Marković 1994: 104), iako je u posljednjih tridesetak godina prisutan sve veći broj radova u kojima se obrađuje badenski materijal; poglavito s nalazišta Vučedol (Težak-Gregl 1985; 1987; 1988), a dosta pažnje posvećeno je i metalurškoj produkciji te kulture (Durman 2000). Zasad jedini cjelovito prikazan i obrađen materijal je onaj s nalazišta Josipovac Punitovački - Veliko polje I (Čataj 2009).

\section{Problem porijekla i periodizacije}

Nekoliko je stavova o porijeklu badenske kulture, od nordijskog, autohtonog, jugoistočnog ili istočnostepskog (Dimitrijević 1979: 224-229).

Nordijsko porijeklo zastupali su 0 . Menghin, R. Pittioni i R. R. Schmidt s tim da je Schmidt ušao u direktnu proturječnost jer je u istoj objavi iznio i ideju o autohtonom podrijetlu badenske kulture i to upravo na osnovi nalaza iz Bapske i Sarvaša, gdje u sloju II vidi protobadensku kulturu (Schmidt 1945: 129). Tezu o autohtonom porijeklu neki autori (npr. V. Nemejcová-Pavúková, I. Torma, M. Garašanin) zastupali su upravo na osnovi grupe Boleraz u kojoj vide sličnosti s vinčanskom, sopotskom, kasnom lengyelskom, lasinjskom i kulturom Ludanice. Neki autori su na osnovi grupe Boleraz porijeklo kulture vukli iz istočne pontske oblasti (Tasić 1982-1983). Tezu o jugoistočnom, odnosno culture in Croatia are not especially numerous and significant in relation to the number of known sites ascribed to this culture (Marković 1994: 222, map 12), a fact that makes it almost impossible to create a general overview of this cultural occurrence.

A wider interest into the problems surrounding the Baden culture is seen in the works of S. Dimitrijević. His paper, published in Arheološki radovi i rasprave (Dimitrijević 1962), was the first attempt at classifying material of the Baden culture from the territory of Croatia (although the paper also includes material from Vojvodina), and to create a periodization. $\mathrm{N}$. Tasić also tackled the issue of the Baden culture from Croatian sites (1967). Although it included many fundamental deficiencies, R. R. Schmidt's work (1945) is important because it was the first attempt at collecting material from Croatia, and studying it as a separate culture.

Expert publications are still permeated by the opinion that the Baden culture was a peripheral and short occurrence on Croatian territory, regardless of the large number of sites ascribed to it (Markovic 1994: 104). However, in the last thirty years or so, the number of publications discussing material of the Baden culture has been increasing, especially from the site of Vučedol (Težak-Gregl 1985; 1987; 1988). A lot of attention was also given to the metallurgy of this culture (Durman 2000). So far, the only completely presented and studied material is the one excavated at the site of Josipovac PunitovačkiVeliko polje I (Čataj 2009).

\section{The problem of origin and periodization}

There are several opinions on the origins of the Baden culture, including Nordic, autochthonous, southeastern and that from the eastern steppes (Dimitrijević 1979: 224-229).

Nordic origin was supported by 0 . Menghin, R. Pittioni and R. R. Schmidt, whereby Schmidt contradicted himself by proposing, in the same publication, the idea of an autochthonous origin of the Baden culture, based precisely on the finds from Bapska and Sarvaša, sites where he saw the protoBaden culture in layer II (Schmidt 1945: 129). Some authors (e.g. V. Nemejcová-Pavúková, I. Torma, M. Garašanin) supported the autochthonous origin hypothesis based on the Boleraz group that displayed similarities to the Vinča, Sopot, late Lengyel, Lasinja and Ludanice cultures. Based on the Boleraz group, some authors thought that the culture origi- 
anatolskom porijeklu badenske kulture prvi je iznio V. Milojčić (1959), a dalje ju je temeljito i argumentirano obrazložio N. Kalicz (1963). S. Dimitrijević i I. Torma iznijeli su mišljenje da se ta teza ne smije zanemariti, ali da je važeća samo za klasičnu fazu badenske kulture. Naime, prema S. Dimitrijeviću badenska je kultura (odnosno Boleraz) nastala u južnim dijelovima Balkana na periferiji kasne vinčanske kulture, dok je važan doprinos anatolskih utjecaja u oblikovanju njezine klasične fizionomije (Dimitrijević 1979: 227-229). Istočnu, stepsku komponentu također možemo vidjeti, ona je naime potvrđena antropološkim podacima te načinom pokopavanja (Težak-Gregl 1985).

Prvi pokušaj periodizacije badenske kulture napravljen je pedesetih godina prošloga stoljeća: Foltiny i Ohrenberger (1952) na osnovi nalaza Neusiedel am See razlučili su dva horizonta badenske kulture, stariji i mlađi. Pittioni (1954) je toj podjeli, odnosno ranoj i srednjoj fazi, još dodao i kasnu fazu, odnosno tip Ossarn. Korak dalje učinio je J. Neustupny (1959) podijelivši badensku kulturu na pet stupnjeva: A - Boleraz, B - Fonyod, C - Uny, D Ossarn, E - Bošaca.

Dimitrijevićeva podjela badenske kulture u osnovi se nadovezuje na onu Neustupny-a uz određene korekcije, napravljene najviše na osnovi stratigrafije lokaliteta Vučedol. On je badensku kulturu podijelio na tri stupnja: A - rana ili pretklasična faza, B - rana klasična faza i C - kasna klasična faza (Dimitrijević 1979: 194-195).

Za prostor središnje Europe prihvaćena je periodizacija V. Němejcove-Pavúkove kojom se u osnovi badenska kultura dijeli na Baden - Boleraz i na klasični Baden (Němejcová-Pavúková 1981; 1991; Wild et al. 2001: 1058).

Glavni problem i kod periodizacije i kod pitanja porijekla badenske kulture predstavlja njezina rana, osnivačka faza: naime, grupa Boleraz smatrana je kao razvojna faza u razvoju badenske kulture, kao protobadenski horizont, kao samostalna kulturna grupa ili kao dio kulturnog kompleksa Cernavoda III. Ovo posljednje se tumači istim ili sličnim formama posuda, istom ornamentikom i naposljetku složenim procesom pomicanja indoeuropskog stanovništva od istoka prema zapadu i njihova prodora u Panonsku nizinu. U sklopu tih pokreta dolazi i do pomicanja Salcutza IV i formiranja nekih novih kratkotrajnih kultura kao što je Hunyadi-Vajska. nated from eastern Pontus (Tasić 1982-1983). The hypothesis about a southeastern, i.e. Anatolian, origin of the Baden culture was originally proposed by V. Milojčić (1959), and was further coherently explained by N. Kalicz (1963). S. Dimitrijević and I. Torma were of the opinion that the hypothesis could not be neglected, but that it was only valid for the classical phase of the Baden culture. Namely, according to S. Dimitrijević, the Baden culture (i.e. Boleraz) formed in the southern parts of the Balkans, on the periphery of the late Vinča culture, with important influences from Anatolia that affected the formation of its classical physiognomy (Dimitrijević 1979: 227-229). The eastern, stepperelated, component is also visible, seeing as it was confirmed by anthropological data and burial rites (Težak-Gregl 1985).

The first periodization of the Baden culture was made during the 1950s: based on finds from Neusiedel am See, Foltiny and Ohrenberger (1952) proposed two phases of the Baden culture, the older and the younger. Pittioni (1954) added a late phase, the Ossarn type, to this division into the early and the middle phase. A step further was made by J. Neustupny (1959), who divided the Baden culture into five phases: A-Boleraz, B-Fonyod, C-Uny, D-Ossarn, E-Bošaca.

Dimitrijevićev's division of the Baden culture is fundamentally linked to the one made by Neustupny, with certain corrections, based mostly on the stratigraphy of Vučedol. He divided the Baden culture into three phases: A-early or pre-classical phase, B-early classical phase, and C-late classical phase (Dimitrijević 1979: 194-195).

In central Europe, V. Němejcova-Pavúková's periodization is generally accepted, wherein the Baden culture is divided into the Baden-Boleraz and the classical Baden (Němejcová-Pavúková 1981; 1991; Wild et al. 2001: 1058).

The main problem of the periodization and the origin of the Baden culture is its early, founding phase: namely, the Boleraz group was seen as a phase in the development of the Baden culture, as a protoBaden phase, as an independent cultural group, and as part of the Cernavoda III cultural complex. The latter is explained based on same, or similar, forms of vessels, uniform ornamentation and, finally, the complex process of Indo-European migrations from east to west and their entry into the Pannonian plain. During these migrations, the Salcutza IV also shifted, and some new and short-lasting cultures, such as Hunyadi-Vajska, were formed. 


\section{Apsolutno datiranje}

Serija apsolutnih datuma na lokalitetima u središnjoj Europi potvrdila je da se ne može izdvojiti protoboleraz faza koju je uveo N. Kalicz (2001) jer se datumi s lokaliteta pripisanih toj fazi u potpunosti podudaraju s onima grupe Boleraz, koji pokrivaju razdoblje između 3630. i 3360. god. pr Kr. (Horváth et al. 2008: 452; Wild et al. 2001: 1062). Slični datumi dobiveni su i za Cernavoda I, po čemu bi se negirao paralelizam između Boleraz i horizonta Cernavoda III, odnosno pokazuje se da je Boleraz stariji od horizonta Cernavoda III (Wild et al. 2001: 10621063). Također datumi su pokazali da su Sitagroi IV, Cernavoda III i Ezero XIII-VII paralelni s klasičnom fazom badenske kulture, a ne kako se isprva mislilo s grupom Boleraz (Wild et al. 2001; Stadler et al. 2001). Navedeni prioritet Boleraza, kao i sličnost u keramičkim oblicima i ukrašavanju posuđa između Boleraza i Cernavoda III vode neke autore do zaključka da je grupa Boleraz nastala na prostoru Donje Austrije, Moravske, Slovačke, zapadne Mađarske i onda se proširila prema jugoistoku (Wild et al. 2001; Stadler et al. 2001: 544), što je uostalom već nagovijestio i Maran (1998).

Prosječno trajanje klasične badenske kulture na prostoru jugoistočne Europe procjenjuje se oko 3360-2995. god. pr. Kr., dok se kasni (IV) stupanj datira do cca 2800. god. pr. Kr. (Bankoff \& Winter 1990: 188, T. 3; Forenbaher 1993: 246; Horváth et al. 2008: 453-454; Horvath 2012: table 7; Rajković, Balen 2016: 60-62).

Apsolutni datumi dobiveni za badensku kulturu na području sjeverne Hrvatske potječu s nekoliko nalazišta. S položaja vinograd Streim na Vučedolu iz istraživanja vođenih od 1984. do 1990. godine (sonde V-84 i V-85) potječu četiri badenska datuma napravljena na ugljenu, a jedan na kosti, u rasponu od 3350. do 2900. god. pr. Kr. (Horvatinčić et al. 1990: 247, T. 2) čime se potvrđuje da je naselje Vučedol bilo naseljeno u klasičnoj fazi badenske kulture.

Istraživanjima istoga položaja, vođenima nakon 2000. godine (sonda V-87) dobiveno je 7 apsolutnih datuma, sve iz ukopanih objekata (jama). Šest datuma smješteno je od 3370. do 3100. god. pr. Kr., dok je jedan datum nešto stariji, odnosno uklapa se u datume dobivene za grupu Boleraz na prostoru središnje Europe (3490. - 3470. god. pr. Kr.) (Balen 2010: tabla 5; Balen 2016: 65-66; Balen 2018: 68, bilj. 53).

\section{Absolute datation}

A series of absolute dates from sites in central Europe confirmed that the proto-Boleraz phase, introduced by N. Kalicz (2001), cannot be confirmed, because dates obtained from sites ascribed to that phase completely overlap with those of the Boleraz group, dated to between 3630 and $3360 \mathrm{BC}$ (Horváth et al. 2008: 452; Wild et al. 2001: 1062). Similar dates were also obtained from Cernavoda I, thereby negating the parallel existence of Boleraz and Cernavoda III phases, i.e. showing that Boleraz is older than the Cernavoda III phase (Wild et al. 2001: 10621063). Additionally, dates have shown that Sitagroi IV, Cernavoda III and Ezero XIII-VII are parallel to the classical phase of the Baden culture, and not, as was originally thought, to the Boleraz group (Wild et al. 2001; Stadler et al. 2001). The listed anteriority of Boleraz, as well as similarities in pottery forms and decorations between Boleraz and Cernavoda III, made some authors conclude that the Boleraz group developed in Lower Austria, Moravia, Slovakia and western Hungary, and then spread towards the southeast (Wild et al. 2001; Stadler et al. 2001: 544), as had been suggested by Maran (1998).

The average datation of the classical Baden culture in southeastern Europe is estimated to be between about 3360 and $2995 \mathrm{BC}$, while the late (IV) phase is dated to app. 2800 BC (Bankoff \& Winter 1990: 188, PI. 3; Forenbaher 1993: 246; Horváth et al. 2008: 453454; Horváth 2012: table 7; Rajković, Balen 2016: 60$62)$.

Absolute dates of the Baden culture in northern Croatia were obtained from several sites. The Vinograd Streim position at Vučedol, excavated between 1984 and 1990 (trenches V-84 and V-85), yielded four dates of the Baden culture from charcoal, and one from bone. The dates range from 3350 to 2900 BC (Horvatinčić et al. 1990: 247, Pl. 2), and confirm that the settlement at Vučedol was inhabited during the classical phase of the Baden culture.

Excavations conducted at the same position after 2000 (trench V-87) yielded 7 absolute dates, all from dugout structures (pits). Six dates fall to the range between 3370 and $3100 \mathrm{BC}$, while one is somewhat older, i.e. it fits overlaps with dates of the Boleraz group in central Europe (3490-3470 BC) (Balen 2010: table 5; Balen 2016: 65-66; Balen 2018: 68, note 53).

The stratigraphy of Vučedol shows that the tell was inhabited during at least two phases. Specifically, a layer of the Baden culture was defined above the 
Stratigrafija Vučedola i pokazuje najmanje dvije faze naseljavanja tela - naime, iznad ukopanih objekata u zdravici, ustanovljen je sloj badenske kulture. Iznad njega je tanki sloj u kojemu se nalazi miješani materijal badenske i kostolačke kulture (svojevrsni sloj nivelacije), zatim kostolačke te na kraju vučedolske kulture.

S nalazišta Josipovac - Gravinjak napravljena je serija od 15 apsolutnih datuma u rasponu od 3630. do 2870 . god. pr. Kr. što se u potpunosti poklapa s dobivenim badenskim datumima s prostora srednje Europe (Balen 2010: tabla 5). Analizom građe i njihovom usporedbom $s$ dobivenim datumima može se zaključiti da je naselje u Josipovcu trajalo tijekom grupe Boleraz i klasične badenske kulture. Materijalu iz ukopanih objekata koji su nešto više datirani (oko 3500. god. pr. Kr.) možemo naći analogije u oblicima i načinu ukrašavanja Boleraz grupe. Zanimljivi su datumi iz dva objekta u Josipovcu koji pokazuju dosta kasne datume, odnosno od cca 3000. do 2870. god. pr. Kr.. po čemu bismo mogli zaključiti da se na tom prostoru badenska kultura zadržala nešto duže, odnosno i u svojoj kasnijoj fazi. Tome potvrdu imamo i na nalazištima oko Belog Manastira, kao i Donjeg Miholjca (Nodilo 2012: 14). Naime, još je S. Dimitrijević, na osnovi keramičke građe naselje na položaju Ciglana u Belom Manastiru pripisao stupnju C ili kasnoj klasičnoj badenskoj fazi (Dimitrijević 1979: 216). To nam potvrđuje i dobiveni datum sa zaštitnih arheoloških istraživanja na položaju Šumarina-Benga, 2895-2705. god. pr. Kr. (Beta-439010: 4220 \pm 30 BP). Mišljenja smo da bi obližnje naselje na položaju Popova zemlja u Belom Manastiru također moglo pripadati navedenom razdoblju. $S$ tog je naime nalazišta dobiven jedan AMS datum, 4176 $\pm 28 \mathrm{BP}$; analiziran je ukop mlađeg muškarca (grob 17), koji je međutim pripisan vučedolskoj kulturi (Janković \& Novak 2018). Determinacija ukopa kao vučedolskog napravljena je isključivo na temelju datuma, jer je u grobu pronađena atipična keramika, koja se ne može sa sigurnošću atribuirati vučedolskoj kulturi. Kako $s$ tog nalazišta prema keramičkom repertoaru imamo prisutnu samo kasnu fazu vučedolske kulture, datum bi mogao pripadati kasnoj badenskoj kulturi, za što imamo analogije na obližnjem nalazištu Šumarina-Benga. Svakako, tek će nam detaljna obrada građe moći u potpunosti rasvijetliti to pitanje.

S nalazišta Štrosmajerovac kod Đakova potječu dva apsolutna datuma, a kreću se u rasponu od 3258. do 3097. god. pr. Kr., a slični datumi dobiveni structures dug into the sterile layer and, above it, there was a thin layer with mixed material of the Baden and Kostolac cultures (a type of levelling), followed by the Kostolac and Vučedol cultures.

The site of Josipovac-Gravinjak yielded a series of 15 absolute dates, ranging from 3630 to $2870 \mathrm{BC}$, and completely overlapping with dates of the Baden culture in central Europe (Balen 2010: table 5). The analysis of material and comparisons to obtained dates lead to the conclusion that the settlement at Josipovac existed during both the Boleraz group and the classical phase of the Baden culture. The material from dugout structures with higher datations (around $3500 \mathrm{BC}$ ) is analogous to forms and decorations of the Boleraz group. Two, quite late, dates from dugout structures at Josipovac, app. 3000 to $2870 \mathrm{BC}$, are interesting because they indicate that the Baden culture was present in the area for a long time, i.e. in its late phase as well. This is additionally confirmed by sites around Beli Manastir and Donji Miholjac (Nodilo 2012: 14). Namely, S. Dimitrijević had, based on pottery, ascribed the settlement at the Ciglana position in Beli Manastir to the $\mathrm{C}$, or the late classical phase of the Baden culture (Dimitrijević 1979: 216). This was confirmed by dates obtained from rescue excavations of the ŠumarinaBenga position, which range from 2895 to $2705 \mathrm{BC}$ (Beta-439010: $4220 \pm 30$ BP). The author feels that the nearby settlement at the Popova zemlja position in Beli Manastir could also be ascribed to the same period. A single date was obtained from an analyzed grave of a young man (grave 17), 4176 $\pm 28 \mathrm{BP}$, which was ascribed to the Vučedol culture (Janković \& Novak 2018) based exclusively on the listed date. The grave yielded atypical pottery that could not be definitively ascribed to the Vučedol culture. Seeing as the rest of the pottery assemblage from the site indicates the presence of the Vučedol culture in its late phase, the date could be connected to the late Baden culture, as indicated by analogies at the nearby site of Šumarina-Benga. Naturally, only a detailed analysis of the material will help shed light on the issue.

The site of Štrosmajerovac near Đakovo yielded two absolute dates, ranging from 3258 to 3097 BC. Similar dates were obtained at the nearby site of Grabrovac (Rajković \& Balen 2016: 61).

Based on the dates (app. 3300-3200 BC), other sites around Đakovo: Kaznica and Palača near Tomašanci (Balen 2010: table 5), can be ascribed to the classical phase of the Baden culture. 
su i s obližnjeg nalazišta Grabrovac (Rajković \& Balen 2016: 61).

Razdoblju klasične faze badenske kulture prema dobivenim datumima (cca 3300-3200. god. pr. Kr.) pripadala bi i ostala nalazišta u okolici Đakova: Kaznica i Palača kod Tomašanaca (Balen 2010: tablica 5).

Rano badensko - Boleraz naselje prema datumima (3640. - 3340. god. pr. Kr.) bilo je i u Velikom polju I (Čataj 2009), a vjerojatno i u Starim Mikanovcima (Miloglav 2016: 104, tablica 1), te sudeći po keramičkoj produkciji i u Velimirovcu - položaj Arenda 1 (Jurković 2012: 49) Za nalazište Štrosmajerovac - Pustara mišljenja smo da bi moglo biti naseljeno tijekom rane (Boleraz) i klasične badenske kulture jer dio materijala pokazuju dosta analogija s drugim nalazima grupe Boleraz (Hršak \& Bojčić 2008), dok apsolutni datum pripada klasičnoj badenskoj kulturi. Slično se može zaključiti i za nalazište Grabrovac kod Đakova (Hršak 2010: 22).

Na prostoru SZ Hrvatske na nekoliko je nalazišta potvrđeno postojanje naselja koja bismo također mogli pripisati grupi Boleraz: Gornji Pustakovac, Barbarsko, Crkvišće i Turčišće (Bekić 2006: 186, T.1:1,4; Balen \& Drnić 2014: 48; Čataj 2016: str. 182, fig. 4; Balen 2018: 69) ili kao u Sloveniji, jednoj kulturnoj grupi nastaloj na lokalnoj tradiciji s prisutnim boleraskim utjecajima (Velušček 2009: str. 28-34).

\section{Naselja}

lako danas možemo govoriti o velikom broju badenskih lokaliteta, pogotovo na prostoru istočne Hrvatske, činjenica je, da su, kao što je uglavnom problem i s ostalim eneolitičkim kulturama, tek na malom broju provedena istraživanja koja nam mogu reći nešto o organizaciji naselja badenske kulture.

Nosioci badenske kulture pretežno su naseljavali riječne terase ili izdanke brežuljaka. I na prostoru Hrvatske vidimo tako da su sva naselja u blizini velikih rijeka, Dunava, Save i Drave. A. Durman smatra da je Vučedol najvažnije i najznačajnije naselje badenske kulture i ishodište u smjeru zapada, odnosno prema Slavonskom Brodu te dalje prema Bosni, odnosno srednjobosanskim rudištima iz kojih se badenska kultura opskrbljivala rudom (Durman 2000: 100). Srednjobosanski rudonosni bazen je, naime, bogat sinjavcima nužnim za proizvodnju arsenske bronce.
As indicated by dates (3640-3340 BC), an early Baden-Boleraz settlement existed at Veliko polje I (Čataj 2009), and probably also at Stari Mikanovci (Miloglav 2016: 104, table 1). Based on pottery production, there might also have been one at Velimirovac - the Arenda 1 position (Jurković 2012: 49). The author feels that the settlement at ŠtrosmajerovacPustara might have been inhabited during the early (Boleraz) and the classical phase of the Baden culture, because some of the material is analogous to other finds of the Boleraz group (Hršak \& Bojčić 2008), while the absolute date falls into the range of the classical Baden culture. A similar conclusion can be made about the site of Grabrovac near Đakovo (Hršak 2010: 22).

In NW Croatia, several sites yielded remains of settlements that could also be ascribed to the Boleraz group: Gornji Pustakovac, Barbarsko, Crkvišće and Turčišće (Bekić 2006: 186, PI. 1:1, 4; Balen \& Drnić 2014: 48; Čataj 2016: 182, fig. 4; Balen 2018: 69), or, like in Slovenia, to a single cultural group that developed on local traditions with Boleraz influences (Velušček 2009: 28-34).

\section{Settlements}

Despite the fact that it is, today, possible to speak of a large number of sites of the Baden culture, especially in eastern Croatia, the fact remains that, as is the case with most Eneolithic cultures, only a small number of them have been excavated in a way that could give information on the settlement organization of the Baden culture.

Populations of the Baden culture mostly inhabited river terraces or hillslopes. On Croatian territory, it is also visible that all settlements are in the vicinity of large rivers, the Danube, the Sava, and the Drava. A. Durman thinks that Vučedol is the most important and most significant settlement of the Baden culture, and the point from which it spread westwards, i.e. towards Slavonski Brod and further into Bosnia or, more precisely, the mining sites of central Bosnia where the Baden culture obtained ore (Durman 2000: 100). The ore-rich basin in central Bosnia is rich in sulfide ore that is necessary for the production of arsenic bronze. 
Po nekim tumačenjima badenska kultura proteže se samo oko i uz rijeku Dunav, a nalazi badenske kulture koji se nalaze na udaljenim lokalitetima, odnosno izvan glavnog distribucijskog prostora vjerojatno se nalaze u sklopu neke druge, lokalne kulture kamo su dospjeli trgovinom ili razmjenom (Horváth et al. 2008: 456).

lako je poznat dosta veliki broj badenskih nalazišta na prostoru Slavonije tek je na malom broju badenskh naselja ustanovljeno postojanje čvrstih nadzemnih objekata. Građeni su u tradicionalnoj maniri za razdoblje kamenoga i bakrenoga doba: nabijeni zemljani pod, zidna konstrukcija od kolja i pruća koja je zatim oblijepljena ilovačom te krov od trske ili slame. Većina naselja su kratkotrajna s vrlo tankim kulturnim slojem, izuzev stratigrafije Vučedola, Sarvaša i Bapske.

R.R. Schmidt navodi postojanje nadzemnih kuća u badenskom sloju na Sarvašu i Vučedolu. Međutim moramo naglasiti, iako je u literaturi već dosta o tome raspravljano, da za Schmidtovih istraživanja na Vučedolu i Sarvašu kostolačka kultura nije bila izdvojena kao zasebna kulturna pojava, nego su kostolački nalazi pripisani starijoj, badenskoj kulturi. Tako na oba lokaliteta imamo po dva badenska sloja, a vjerojatnije je da je jedan, onaj gornji, zapravo kostolački (Rajković \& Balen 2016: 62).

Revizijom građe s vučedolskoga Gradca potvrđeno je postojanje jakoga kostolačkog sloja, što se potvrđuje i daljnjjim istraživanjima na vučedolskom kompleksu, jednako kao i pripadnost apsidnih kuća kostolačkoj kulturi (Tasić 1979: 249; Nikolić 2000: 42-43; Balen 2002: 44). Ipak, situacija na Sarvašu nije posve jasna; slojevi su uleknuti, a i dokumentacija je manjkava. Primjer Vučedola, gdje je unutar badenskog sloja tijekom novijih istraživanja položaja vinograd Streim potvrđeno postojanje nadzemnih objekata, upozorava da se ipak ne smije posve isključiti postojanje nadzemnih objekata u sklopu badenske kulture niti na Sarvašu.

Istraživanja na Vučedolu pokazuju da je riječ o jednom dugotrajnijem badenskom naselju: najstarija faza je ukopana u zdravicu, a zatim slijedi bogati sloj debljine i do $60 \mathrm{~cm}$ (Težak-Gregl 1985: 24). Uglavnom je riječ o ukopanim jamskim objektima od kojih možemo razlikovati duboke, pravilne jame koje se šire prema dnu, koje su najvjerojatnije isprva imale funkciju spremišta te su potom služile i kao otpadne, te plitke jame nepravilnija oblika koje su vjerojatno bile radne. Naime, u nekima je pronađena velika količina lomljevine (jezgre, sječiva, od-
According to some interpretations, the Baden culture spread only around and along the Danube, and finds of the Baden culture that were discovered outside of the main distribution area were probably part of some other, local, culture that obtained it through trade or exchange (Horváth et al. 2008: 456).

Even though a large number of sites of the Baden culture is known from Slavonia, the existence of firm above-ground structures was confirmed only at some. These were built in the traditional Stone and Copper Age way: earthen floors, wall constructions made of wattle that was then covered in clay, and a roof made of reed or hay. Most settlements were used for a short period of time and contained very thin cultural layers, with the exception of the stratigraphy of Vučedol, Sarvaš, and Bapska.

R. R. Schmidt recorded the existence of aboveground structures in the Baden layer at both Sarvaš and Vučedol. However, it is important to note that, although it has been widely discussed in publications, during Schmidt's excavations of Vučedol and Sarvaš, the Kostolac culture was not yet seen as a separate cultural occurrence, and the material was ascribed to the older Baden culture, which is why two layers of the Baden culture were defined at both sites. However, it seems more likely that one of them, the upper one, should actually be ascribed to the Kostolac culture (Rajković \& Balen 2016: 62).

A revision of material from the Gradac position at Vučedol confirmed the existence of a strong layer of the Kostolac culture, which was confirmed by subsequent excavations of the Vučedol complex. Apsidal houses were also attributed to the Kostolac culture (Tasić 1979: 249; Nikolić 2000: 42-43; Balen 2002: 44). However, the situation at Sarvaš is not completely clear; the layers were sunken, and the documentation incomplete. The example of Vučedol, where the Baden layer at the Vinograd Streim position, excavated in more recent times, confirmed the existence of above-ground structures, suggests that above-ground structures might have existed in the context of the Baden culture at Sarvaš as well.

The excavations of Vučedol indicate the existence of a long-term settlement of the Baden culture: the oldest phase is dug into the sterile layer, and was followed by a rich 60-cm-thick layer (Težak-Gregl 1985: 24). The finds mostly include dugout pit structures that can be divided into deep, regular pits that widen towards the bottom, and which probably origi- 
Slika / Figure 1. Kupolasta peć s taracom od keramike, Vučedol - vinograd Streim, sonda $\mathrm{V} / 87$, istraživanja 2005. godine / A domeshaped kiln with pottery at the base, Vučedol-Vinograd Streim, trench V/87, the 2005 excavations (foto / photo: J. Balen).

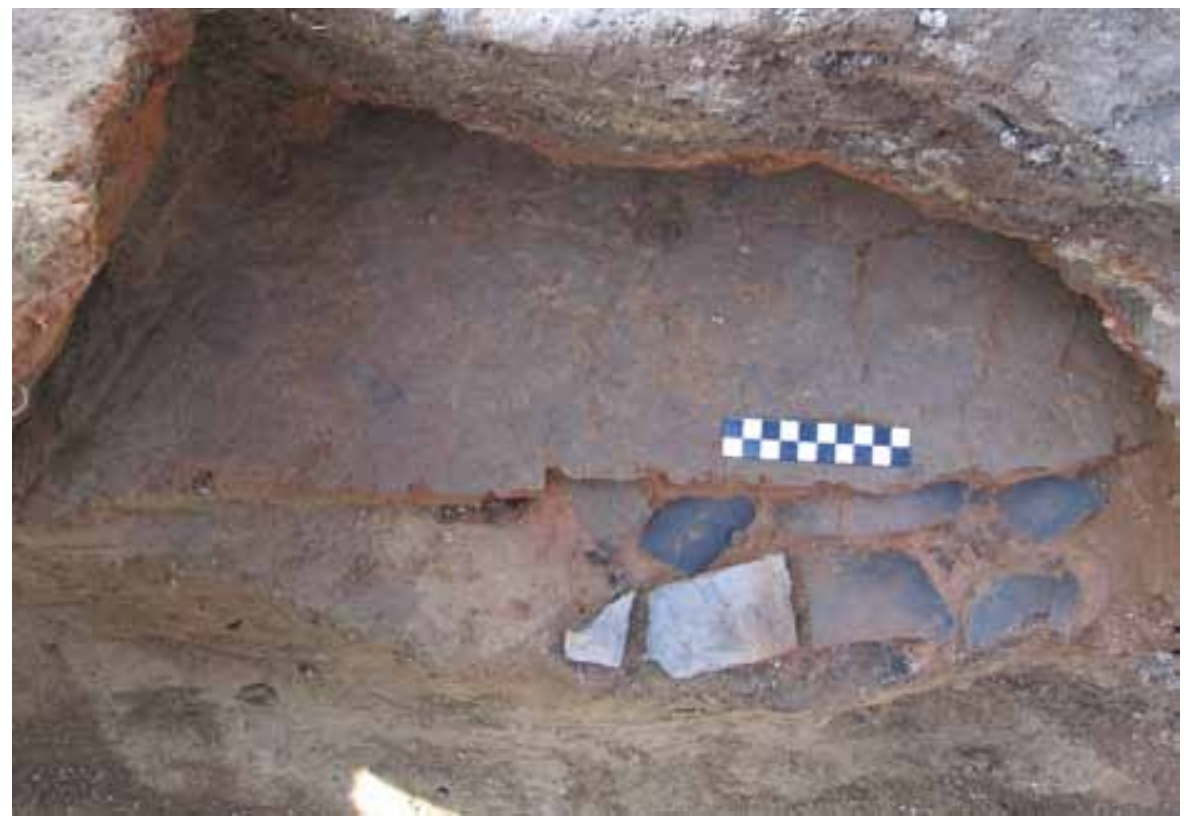

bojci, krhotine) zbog čega i mislimo da je u njima bio obrađivan kamen. Dio većih, nepravilnih jama, neki autori tumače i kao stambene (Durman 1984: 36). Nepravilni naboji žuta prapora kao i zapečeni naboji podnica najvjerojatnije su od nadzemnih objekata, međutim njihov točan oblik teško je definirati jer su uglavom ispresijecane jamama (Durman \& Balen 2005: 30; Balen 2004: 66; Balen 2006: 44). Na otvorenom, uz stambene objekte pronalažena su i ognjišta i kupolaste peći s taracom od keramike koje se nalaze u jamama (Durman 1984: 36; Durman 1987: 35; Balen 2006: 44), za što imamo analogije na brojnim badenskim lokalitetima (Endrődi-Gyulai 1998/2000: fig. 21; Endrődi 2004: 14, sl. 8; Čataj 2009: 120).

Tragovi nadzemnih objekata spominju se i u Aljmašu - položaj Podunavlje (Šimić 2001: 73; 2006: 7). Nažalost, za nalaze triju kupolastih peći nije sasvim sigurno pripadaju li eneolitičkom stratumu (Šimić 2001: 73-74).

Tragovi nadzemnih objekata ustanovljeni su na nalazištu Donji Miholjac - Panjik, gdje su istraženi dijelovi stambenog i radnog dijela naselja badenske kulture (Ložnjak Dizdar et al. 2016).

Kao naselje s pronađenim isključivo jamskim objektima navodi se ono na položaju Grabrovac kod Đakova (Pavlović 1984), na položaju Štrosmajerovac kod Đakova (Hršak \& Bojčić 2008), na položaju Gravinjak kod Josipovca (Mihelić 2008), Veliko polje I kod Josipovca Punitovačkog (Čataj 2009), nally functioned as storage, and later as waste pits, and shallow irregular pits that were probably used as working areas. To be exact, some of them yielded large amounts of chipped stone (cores, blades, flakes, chunks), suggesting that they were used to process stone. Some larger irregular pits have been interpreted by some authors as habitational structures (Durman 1984: 36). The irregular compacted yellow loess and burnt house floors were most likely parts of above-ground structures, but their exact shape is difficult to determine because they were mostly cut by other pits (Durman \& Balen 2005: 30; Balen 2004: 66; Balen 2006: 44). Hearths and domeshaped kilns with pottery fragments at their base have been discovered in pits in the open, next to habitational structures (Durman 1984: 36; Durman 1987: 35; Balen 2006: 44), a situation that is analogous to that found at numerous sites of the Baden culture (Endrődi-Gyulai 1998/2000: fig. 21; Endrődi 2004: 14, fig. 8; Čataj 2009: 120)

Traces of above-ground structures are also mentioned at Aljmaš - the Podunavlje position (Šimić 2001: 73; 2006: 7). Unfortunately, it is not completely clear if the three dome-shaped kilns can be connected with the Eneolithic layer (Šimić 2001: 73-74).

Traces of above-ground structures were established at Donji Miholjac-Panjik, where a working and a habitational part of a settlement of the Baden culture were discovered (Ložnjak Dizdar et al. 2016). 
Opatovac - Šanac (Ložnjak Dizdar et al. 2014; Ložnjak Dizdar \& Dizdar 2015), Donji Miholjac-ĐanovCi (Tkalčec 2016: 52), Donji Miholjac-Mlaka (Nodilo 2012: 13-14), Donji Miholjac-Čovci (Vodička 2011), Gornji Slatnik-Grabrovac (Bakić-Stojsavljević 2010), Velika Londžica-Malo Polje (Paskojević 2010), Ruščica-Glogove-Praulje i Ruščica-Praulje (Bednjanec 2012a; 2012b; Mihaljević et al. 2018), Saloš kod Donje Vrbe (Lozuk 2006), Vidovci-Rosulje (Mihaljević 2010). Rubni dijelovi badenskih naselja s isključivo plitkim, okruglim jamama, ustanovljeni su $\mathrm{i}$ u Palači kod Tomašanaca i Čepinskim Martincima (Kalafatić 2009).

Prilikom objave istraživanja badenskog naselja u Belom Manastiru K. Vinski Gasparini veće, nepravilne ukopane objekte pripisala je jamama iz kojih se vadila glina, a ne, kao što je to uobičajeno, stambenim zemunicama (Vinski - Gasparini 1956: 13-17). Priklonila se tu mišljenju Pareta koji je upozorio na činjenicu da su u naseljima s nadzemnim objektima popratna pojava jame nepravilna oblika i raznih dimenzija, katkad s rupama od stupova. Smatra da se iz tih jama vadila ilovača kojom su se gradili i popravljali nadzemni objekti te također i keramika. Tragove kolaca tumači kao ogradu postavljenu iz sigurnosnih razloga. Etnografskim paralelama također je ustanovljeno da su velike nepravilne jame korištene za vađenje ilovače i za bacanje otpadaka, kruškolike vertikalne jame $s$ uskim otvorom služile su kao spremišta žitarica, dok jame pravilnijeg tlocrta (ovalnog ili pravokutnog), s relativno ravnom podnicom, služe kao spremišta za razne usjeve. Ukopane nastambe - zemunice pravilnog su pravokutnog oblika te ukopane u zemlju cca 0,70 m.

Svakako zanimljiv nalaz nadzemnih objekata (sojenica) pronađen je na nalazištu Balatonőszöd-Temető dűlő (Horváth et al. 2007). Naime, uz obalu jezera, dakle na plavnom prostoru, ustanovljene su nadzemne kuće čiji su temelji postavljeni u ukopanim jamama dosta nepravilna oblika. Zasad, takvi nadzemni objekti nisu identificirani na hrvatskim nalazištima, makar ne smijemo isključiti moguće postojanje sličnih konstrukcija u nizinskom plavnom području Slavonije jer su neka od novootkrivenih badenskih naselja upravo smještena na takvom prostoru, primjerice Palača kod Tomašanaca.

Nažalost, o organizaciji naselja možemo govoriti samo kod nekoliko naselja. U Salošu su na istraženoj površini od $1650 \mathrm{~m}^{2}$ otkrivena 34 jamska objek-
Only dugout structures have been recorded at the sites of Grabrovac near Đakovo (Pavlović 1984), the Štrosmajerovac position near Đakovo (Hršak \& Bojčić 2008), the Gravinjak position near Josipovac (Mihelić 2008), Veliko polje I near Josipovac Punitovački (Čataj 2009), Opatovac-Šanac (Ložnjak Dizdar et al. 2014; Ložnjak Dizdar \& Dizdar 2015), Donji Miholjac-Danovci (Tkalčec 2016: 52), Donji Miholjac-Mlaka (Nodilo 2012: 13-14), Donji MiholjacČovci (Vodička 2011), Gornji Slatnik-Grabrovac (Bakić-Stojsavljević 2010), Velika Londžica-Malo Polje (Paskojević 2010), Ruščica-Glogove-Praulje and Ruščica-Praulje (Bednjanec 2012a; 2012b; Mihaljević et al. 2018), Saloš near Donja Vrba (Lozuk 2006), and Vidovci-Rosulje (Mihaljević 2010). The periphery of a settlement of the Baden culture, with shallow round pits, was defined at Palača near Tomašanaci and at Čepinski Martinci (Kalafatić 2009).

When publishing the result of excavations conducted at the Baden settlement in Beli Manastir, K. Vinski Gasparini defined all larger irregular dugout structures as clay beds and not, as is customary, pit dwellings (Vinski-Gasparini 1956: 13-17). She agreed with Paret who warned that pits of irregular shape and varying size, sometimes with post holes, often appear in settlements with above-ground structures. The author thought these pits were used to extract clay that was then used to build and repair above-ground structures and to make pottery. Post holes are interpreted as the remains of fences that were built for safety reasons. Ethnographic parallels also helped establish that large irregular pits were used to extract clay and deposit waste, that pear-shaped vertical pits with narrow openings were used to store grains, and that pits with a regular layout (oval or rectangular), with a relatively small floor, were used to store different crops. Dugout dwellings - pit-houses, had a rectangular layout and were about $0.7 \mathrm{~m}$ deep.

An interesting find of above-ground structures (stilt houses) was discovered at Balatonőszöd-Temető dülő (Horváth et al. 2007). Namely, the lake shore, i.e. frequently flooded land, yielded above-ground houses with foundations in dugout pits of irregular shape. So far, such above-ground structures have not been identified on Croatian sites, although it is possible that similar constructions existed in lowland, frequently flooded areas of Slavonia, seeing as some of the newly-discovered sites of the Baden culture are situated precisely in such areas, e.g. Palača near Tomašanci. 
ta, determinirana kao stambeni, radni, spremišta i otpadne jame. Izdvojene su tri cjeline unutar naselja: stambena, metalurška i dio za uzgoj stoke. Stambene zemunice ukopane su u zemlju, imaju do 4 prostorije i veličine su od $6 \mathrm{~m}^{2}$ do $20 \mathrm{~m}^{2}$. Ognjišta su pronalažena i u zemunicama i u vanjskim prostorima (Lozuk 2006: 228-229). Pronađeno je pet peći od čega tri za lijevanje metala. Uz to je bio radni, zemunički prostor, vjerojatno ljevača, što se vidi po kalupima i posudama za lijevanje pronađenim u zemunici. A. Durman smatra da je rudača ugrubo prebirana na rudištima dok je preciznije odvajanje obavljeno u naselju (Durman 2000).

Da se metalurška djelatnost odvijala u sklopu naselja pokazuju nam i lokaliteti Okukalj kod Gornje Bebrine, Štrosmajerovac kod Đakova, a također nam to potvrđuju rezultati zaštitnih istraživanja unutar Luke Slavonski Brod na nalazištima Ruščica-Glogove-Praulje i Ruščica-Praulje, koja su, čini se, tvorila jedinstveno naselje (Bednjanec 2012a; 2012b; Mihaljević et al. 2018).

U sklopu badenskih naselja pronalaženi su i grobovi, ljudski i životinjski, i rijetki primjerci kultnih mjesta. Najbolji primjer tome imamo iz Mađarske gdje je istraženo naselje na površini od $76000 \mathrm{~m}^{2}$ u Balatonőszödu (Horváth 2004). U sklopu naselja pronađeno je čak 49 ljudskih ukopa te je definirano posebno sveto mjesto gdje su se najvjerojatnije odvijale kultne i religijske svetkovine.

\section{Pokapanje}

U Karpatskoj kotlini je u vrijeme razvijenog eneolitika pa tako i u okvirima badenske kulture uobičajeno pokapanje pokojnika izvan naselja u posebnim grobljima. Međutim, na prostoru Hrvatske još uvijek ne možemo govoriti o izdvojenim grobljima izvan naselja nego su pronalaženi sporadični grobovi unutar naselja. lako je za badensku kulturu uobičajen biritualan način pokapanja - u grupi Boleraz karakteristično je paljevinsko pokapanje, dok je u klasičnoj fazi češća inhumacija - na prostoru Hrvatske pronalaženi su dosad samo skeletni ukopi. Razlog tome možda možemo tražiti u činjenici da svi paljevinski ukopi na prostoru Mađarske nisu ukopani u jamu nego su grobovi polagani u ili na humus te su zatim obloženi kamenjem (Dimitri-
Unfortunately, settlement organization can only be discussed based on a few settlements. In Saloš, an excavated area of $1650 \mathrm{~m}^{2}$ yielded 34 pit structures that were defined as habitational and working areas, storage and waste pits. Three units were established within the settlement: habitational, metallurgical and one for keeping cattle. Pit-dwellings were dug into the ground, had 4 rooms and measured between $6 \mathrm{~m}^{2}$ and $20 \mathrm{~m}^{2}$. Hearths were discovered both in pit-dwellings and outside areas (Lozuk 2006: 228-229). Five kilns, three of them for casting metal, were discovered. A dugout area, probably used by a castor, was also discovered, as suggested by accompanying finds of molds and vessels used in casting. A. Durman thinks that ore was roughly screened at the source, and that a more detailed selection was made in the settlement (Durman 2000).

Metallurgical activities took place within the settlement, as indicated by finds from Okukalj near Gornja Bebrina and Štrosmajerovac near Đakovo, as well as the results of rescue excavations of Luka in Slavonski Brod - the sites of Rušcica-GlogovePraulje and Ruščica-Praulje, which, as it seems, comprised a single settlement (Bednjanec 2012a; 2012b; Mihaljević et al. 2018).

Settlements of the Baden culture also yielded graves, human and animal, as well as rare examples of cult-related areas. The best example can be found in Hungary, where a $76000 \mathrm{~m}^{2}$ settlement was excavated at Balatonőszöd (Horváth 2004). The settlement yielded a total of 49 human burials and a specially defined holy place that was, most likely, used during cult-related and religious events.

\section{Burials}

During the developed Eneolithic of the Carpathian basin, including the Baden culture, burying the dead outside settlements in special graveyards was a common practice. However, in Croatia, it is still impossible to speak of separate graveyards outside settlements, because only sporadic burials have been discovered within settlements. Although biritual burials are common in the Baden culture, the Boleraz group is characterized by incineration burials, while inhumation is more common in the classical phase - the territory of Croatia has so far yielded only skeletal burials. The reason behind this might be the fact that all incineration burials in Hungary were not buried in pits, but were placed either onto or into the surface layer and covered 
jević 1979: 202), što znači da su vrlo lako mogli biti uništeni obradom zemlje.

Tijekom istraživanja 1984. god. na Vučedolu - vinograd Streim u dvije su jame pronađeni ukopi pripadnika badenske kulture (Težak-Gregl 1985). Jedan je ukop odrasle osobe, položene na prsa, orijentacije I-Z s prilozima bakrenog bodeža i kremenog noža. Grob je zasut slojem drobljenog kućnog lijepa. Drugi ukop je dječji, orijentacije S-J, položen na leđa, ali sa zgrčenim nogama, bez grobnih priloga. Autorica zasipavanje groba lijepom dovodi u vezu s posipavanjem grobova okerom, što je kao i polaganje pokojnika na leđa s podignutim nogama obilježje stepskih kultura, odnosno kulture grobova u jami.

S Vučedola (sonda V-87, sezona 2004) potječe i nalaz parcijalnog ukopa ljudske lubanje. Sličan nalaz, ali u sklopu zemunice u kojoj su ustanovljeni tragovi zgure i ognjište, zabilježen je i u Okuklju (Petrović \& Belić 1971: 12).

S. Dimitrijević badenskoj kulturi pripisuje i dva groba s vučedolskog Gradca od kojih je Schmidt jedan pripisao badenskoj, a drugi vučedolskoj kulturi (Schmidt 1945: 41-47; Dimitrijević 1979: 202-203); dvojni grob ženskog para i dječju grobnicu u kojoj su bila pokopana tri novorođenčeta, dijete od 6 mjeseci i dijete od 6 godina.

Badenski ukop također imamo posvjedočen i na lokalitetu Josipovac - Gravinjak (Mihelić 2008; Nikotović et al. 2012) kao i na nalazištu Donji Miholjac-Mlaka (Nodilo 2012: 14). U Gravinjaku se radi o ukopu u zgrčenom položaju na lijevome boku, na relativnoj dubini od $50 \mathrm{~cm}$ od površine ukopa jame. Prekriven je pokrovom koji se najvećim dijelom sastoji od lijepa i zemlje, uz nekoliko fragmenata keramike. Dobiveni datum je 3490. - 3470. god. pr. Kr. (Beta 241675).

Na lokalitetu Retfala u Osijeku 1987. godine rovom je presječen kostur djeteta u zgrčenom položaju na lijevom boku. Prekriven je bio slojem riječnih školjki uz keramičke nalaze. Kako je riječ o neukrašenoj keramici grube fakture, ne može se sa sigurnošću reći radi li se o badenskom ili kostolačkom ukopu s obzirom da su u slojevima posvjedočeni nalazi obje spomenute kulture (Šimić 1998: 235).

Već smo naveli problem ukopa s položaja Popova zemlja u Belom Manastiru, za koji smo mišljenja da možda, ipak pripada kasnoj badenskoj kulturi, što uostalom sugeriraju i rezultati istraživanja s drugih naselja u neposrednoj blizini, a ne ranoj with stones (Dimitrijević 1979: 202), meaning that they can be easily destroyed by agriculture.

The 1984 excavations of Vučedol-Vinograd Streim revealed two that contained burials of the Baden culture (Težak-Gregl 1985). One belonged to an adult, who was on his chest; it spread from $E$ to $W$, and contained a copper dagger and a flint knife. The grave was covered by a layer of crushed daub. The second grave belonged to a child, who was on its back with contracted legs; it spread from $\mathrm{N}$ to $\mathrm{S}$, and contained no grave goods. The author connected the crushed daub to the practice of covering graves with ochre that is, just like burying the deceased on their back with raised legs, a characteristic of steppe-related cultures, i.e. the culture of pit graves.

Vučedol (trench V-87, season 2004) yielded a partial burial of a human skull. A similar find, discovered within a pit-dwelling that also contained traces of slag and a hearth, was recorded at Okukalj (Petrović \& Belić 1971: 12).

S. Dimitrijević ascribed two graves from the Gradac position at Vučedol to the Baden culture, and which had Schmidt divided and ascribed one to the Baden, and the other to the Vučedol culture (Schmidt 1945: 41-47; Dimitrijević 1979: 202-203). This was a double burial of a married couple and a children's tomb that included the remains of three newborns, a 6-month-old and a 6-year-old.

Burials of the Baden culture were also discovered at Josipovac-Gravinjak (Mihelić 2008; Nikotović et al. 2012) and Donji Miholjac-Mlaka (Nodilo 2012: 14). At Gravinjak, the deceased was in a crouched position on his left side, at a relative depth of $50 \mathrm{~cm}$ in relation to the top of the pit. The grave was covered by a shroud mostly composed of daub and soil, as well as a few pottery fragments. It was dated to between 3490 and 3470 BC (Beta 241675).

In 1987, a trench cut through the skeleton of a child who was crouching on its left side at the site of Retfala in Osijek. The skeleton was covered with a layer of river shells and ceramic finds. Seeing as the pottery was coarse and undecorated, it is not clear whether this is a grave of the Baden or the Kostolac culture, because material ascribed to both cultures was found in the surrounding layers (Šimić 1998: 235).

The problem of the burial from the Popova zemlja position in Beli Manastir was already mentioned, and the author is of the opinion that it might be 
vučedolskoj kulturi, jer je na nalazištu prisutan isključivo keramički materijal koji možemo pripisati kasnoj vučedolskoj kulturi.

Životinjski ukopi česti su u badenskoj kulturi - i samostalni ukopi životinja i njihovo pokapanje zajedno s ljudima (Dimitrijević 1979: 204-205). Na prostoru Mađarske ustanovljeni su ukopi životinja (najčešće goveda) na čak 23 nalazišta (Endrődi 2003: 410), dok su na prostoru Hrvatske dosad posvjedočena dva ukopa goveda u Aljmašu (Šimić 2001: 73; Šimić 2006: 7), jedan na položaju Retfala u Osijeku (Šimić 2005), jedan na Josipovcu (Mihelić 2008), tri ukopa goveda, od čega jedan dvojni, u naselju na položaju Ruščica-Glogove-Praulje (MihaIjević et al. 2018: 18,19) te ukop goveda i svinje na Vučedolu (Jurišić 1990: 22-23).

\section{Materijalna ostavština}

Kao i na ostalim pretpovijesnim, tako i na badenskim nalazištima keramička produkcija čini najveći postotak ukupnog broja nalaza. Visok, gotovo metalni sjaj crno glačane površine posuđa, vrčevi i šalice kuglastog ili lukovičastog trbuha s visokim cilindričnim vratom i visokom ručkom koja nadvisuje rub posude, često ukrašeni kaneliranjem (SI. 2), kao i plosnate stilizirane figure bez glave (koja je vjerojatno naknadno oblikovana od drta ili nekog organskog materijala) odlika su ove kulturne pojave na čitavom prostoru njezina rasprostiranja. ascribed to the late Baden culture, as suggested by the results of excavations from other settlements in the vicinity, and not to the early Vučedol culture, seeing as the site only yielded material that can be attributed to the late Vučedol culture.

Animal burials are common in the Baden culture both individual animal burials and mixed burials of animals and humans (Dimitrijević 1979: 204-205). In Hungary, animal burials (most often cattle) were recorded at 23 sites (Endrődi 2003: 410), while Croatian territory has, so far, yielded two cattle burials at Aljmaš (Šimić 2001: 73; Šimić 2006: 7), one at the Retfala position in Osijek (Šimić 2005), one at Josipovac (Mihelić 2008), three, one of them double, at the Ruščica-Glogove-Praulje position (Mihaljević et al. 2018: 18,19), and the burial of a bovid and a pig at Vučedol (Jurišić 1990: 22-23).

\section{Material heritage}

Just like at other prehistoric sites, pottery production makes up the largest percentage of the total assemblage at sites of the Baden culture. The characteristics of this cultural occurrence on the entire area it occupied include the high, almost metallic sheen of the black polished surface of vessels, jugs and cups with a rounded or bulbous body with cylindrical necks and tall handles that go over the rim, which are often decorated by fluting (Fig. 2), as well as flat stylized figurines without a head (which was probably additionally made out of wood or some organic material).

Slika / Figure 2. Različiti tipovi šalica s nalazišta Beli Manastir-Ciglana i Popova zemlja / Different types of cups from the sites of Beli ManastirCiglana and Popova zemlja (foto / photo: I. Krajcar)

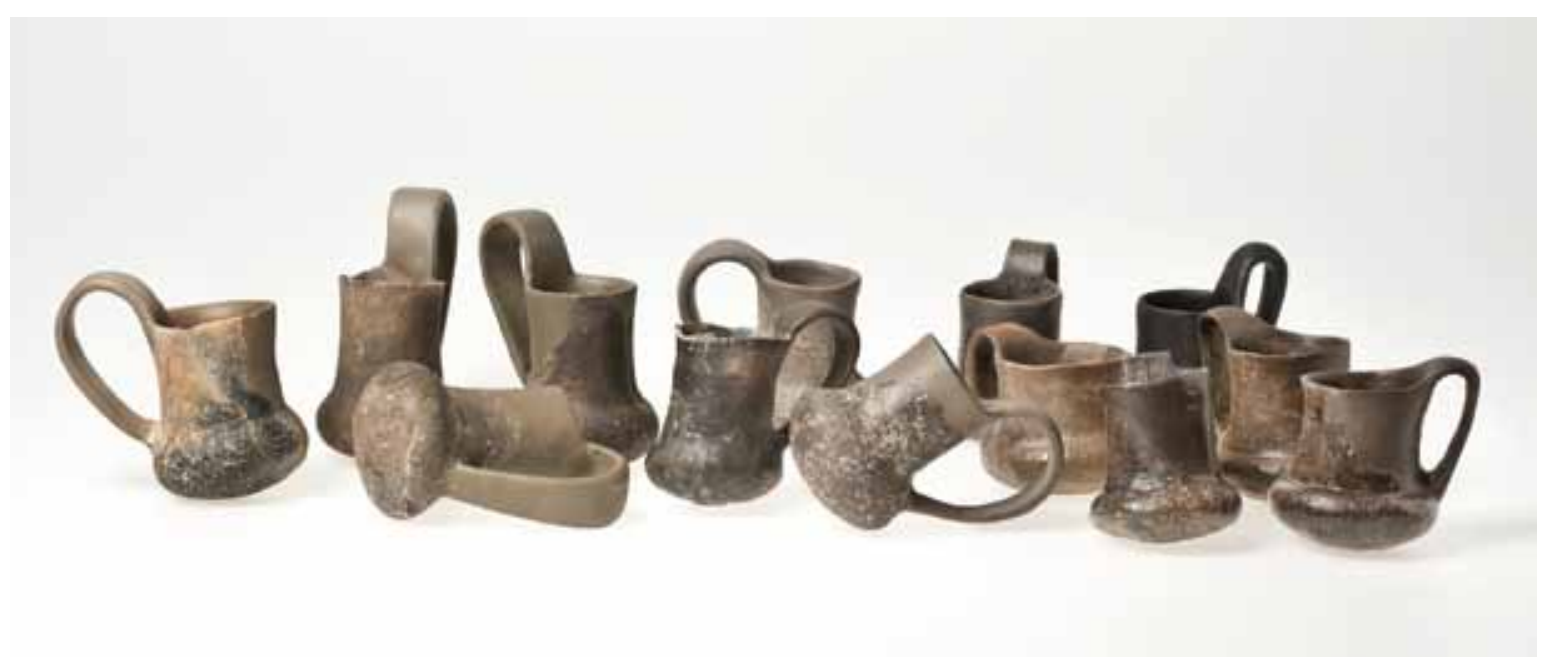




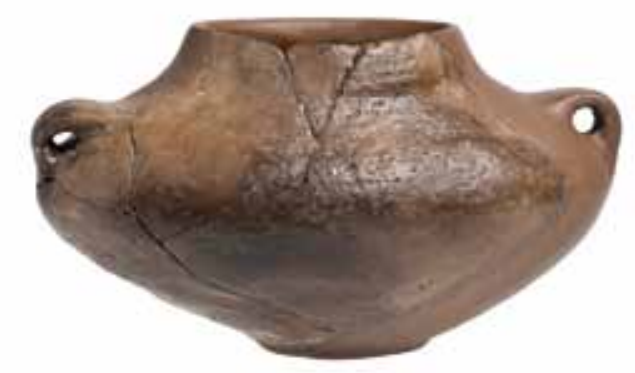

Slika / Figure 3. Posuda izduljenog, vretenastog oblika s lokaliteta Osijek-Retfala / An elongated spindle-like vessel from the site of Osijek-Retfala (foto / photo: I. Krajcar).

Karakterističan je i nalaz posuda izduljenog vretenastog oblika, tzv. Fischbutte (SI. 3), zatim zdjela S-profilirana tijela ili zaobljenih zdjela s ravnim ili uvučenim rubom. Ukras na tipu zaobljenih zdjela često je postavljen pod samim rubom, a na S-profiliranim zdjelama ukras je najčešće na trbuhu, odnosno donjem dijelu posude. Obično je izveden karakterističnim žigosanim ubodima i urezivanjem. Zdjele često imaju ušice na najširem dijelu posude. Lonci su grube fakture s izvučenim vratom $i$ zaobljenim tijelom, ponekad s trakastim ručkama na trbuhu. Ukrašeni su rijetko - žigosanim ili urezanim ukrasom ili barbotinom.

Sasvim različit od klasičnog badenskog keramografskog opusa je onaj grupe Boleraz (SI. 4). Za njega su karakteristične grube, velike posude, širokog ili suženog otvora, redovito vrlo malog promjera dna, bikonične zdjele s gornjim dijelom izvijenim prema van, lonci S-profiliranog tijela, vrčevi kuglastog tijela i kratkog vrata s ručkom. Keramika je uglavnom grube fakture, s velikim postotkom pijeska u sastavu. Ukras je izveden u vidu plastičnih traka sa zarezima ili otiscima u 1-4 reda ispod ruba, ponekad su kombinirane okomite i vodoravne vrpce, zatim kaneliranjem - široke facete ili glačani žljebovi postavljeni su okomito ili koso u unutrašnjosti zdjela ili na ručkama, urezane, okomito postavljene, široke cik-cak vrpce koje prekrivaju cijelu površinu posude i duboko urezani koncentrični krugovi (na zdjelama i poklopcima).

Za kasnije faze badenske kulture karakteristične su dvodijelne posude, odnosno posude s unutar-
Other typical forms include vessels with an elongated spindle-shaped neck - the, so called, Fischbutte (Fig. 3), as well as S-profiled bowls or rounded bowls with a straight or inward-facing rim. Decorations often appear right under the rim on rounded bowls, and on the vessel body or the lower part of S-profiled bowls, and are usually composed of characteristic stamped stabs and incisions. Bowls often have small loops on the widest part. Pots are coarse, have an inverted rim and a rounded body, and, sometimes, ribbon-like handles on the body. They are rarely decorated with stamped or incised motifs and barbotine.

The pottery repertoire of the Boleraz group is completely different from the one of the classical Baden culture (Fig. 4). It is characterized by coarse, large vessels with a wide or narrowed rim and a very narrow base, biconical bowls with an outward-facing neck, s-profiled pots, and jugs with a rounded body, a short neck and a handle. Pottery is mostly coarse and contains a lot of sand. Decorations include plastic ribbons with additional incisions or imprints that appear in 1-4 lines under the rime, occasionally a combination of vertical and horizontal ribbons, fluting - vertical or slanted wide facets or polished gauges on the inside of the vessel, incised vertical zigzag ribbons that cover the entire vessel, and deeply incised concentric circles (on bowls and lids).

The later phases of the Baden culture are characterized by bipartite vessels, i.e. vessels with inner dividers. In that context, a find from Luka Brod (Fig. 5) is interesting, because it poses the question of a longer duration of the Baden culture on a wider territory of Croatia, and not only in the Baranja region.

Unfortunately, other than vessels, very few everyday utilitarian finds from Croatian sites have been published. S. Dimitrijević listed that stone tool production resembled the usual, and that bone finds could be divided into awls and finds made out of deer antlers (Dimitrijević 1979: 219-220). Pits that contained pottery of the Baden culture at Vučedol also yielded ceramic spoons with protrusions for holding, as well as round objects with a funnel-like opening at the center, i.e. models of wheels.

The younger settlement of the Boleraz group at Veliko polje also yielded conical and flat spindles (Čataj 2009: 117).

In the context of the Baden culture, cult-related objects include ceramic models of wagons (mostly discovered in graves), flat stylized figurines with- 
njom pregradom, pa je upravo i zanimljiv nalaz takve posude na poziciji Luka Brod (SI. 5), čime bi se možda otvorilo pitanje dužeg trajanja badenske kulture na širem prostoru sjeverne Hrvatske, a ne isključivo na prostoru Baranje.

O svakodnevnim uporabnim predmetima, osim posuđa, nažalost s hrvatskih nalazišta imamo jako malo objavljenih podataka. S. Dimitrijević navodi da je litička produkcija standardna, a da se koštani predmeti dijele na šila i na predmete načinjene od jelenjih rogova (Dimitrijević 1979: 219-220). S Vučedola u jamama s badenskom keramikom pronalažene su i keramičke žlice s nastavkom za držanje, a čest je i nalaz okruglih keramičkih predmeta sa središnjim cjevastim produžetkom otvora, odnosno modela kotača.

Iz mlađeg, naselja grupe Boleraz u Velikom polju potječu i nalazi pršljenaka koničnog i plosnatog presjeka (Čataj 2009: 117).

Kao kultni predmeti u okviru badenske kulture navode se modeli kola (uglavnom pronalaženi u grobovima), plosnate stilizirane figure bez glave (pronalažene u naseljima), antropomorfne posude, odnosno posude sa stiliziranim prikazima ruku te nalazi kamenih stela - stupova kvadratična oblika od vapnenca koji su visoki $240 \mathrm{~cm}$, a teški oko 600 kg (Endrődi 2003: 410; Endrődi 2004: 27-34). Na prostoru Hrvatske zasad su nam poznate samo četiri figure akefalnog tipa: dvije iz Vučedola (Težak-Gregl 1988) te po jedna iz Aljmaša (Šimić 2001: 73) i Belog Manastira - položaj Popova zemlja (SI. 6) (Los 2016). Zajedno s figurama na Vučedolu su pronađeni i dijelovi modela kola (Težak-Gregl 1988: 13). S Vučedola potječu još dva tipa figura: plosnate, s urezima ispunjenim ubodima (Schmidt 1945: T.29:1) te valjkastog oblika, grube izrade i s motivom urezane prekrižene vrpce na prsima (TežakGregl 1988: 13, bilj. 13). Ulomak figurice trapezastog oblika, grube izrade i bez ukrasa pronađen je u Velikom polju (Čataj 2009: 118-119), a također je jedna figurica pronađena u Grabrovcu kod Đakova (Hršak 2010: 22).

Tip posuda sa stiliziranim rukama kakve su česte na prostoru Mađarske, a pronađene su i u susjednoj Vojvodini, na Gomolavi (Petrović \& Jovanović 2002: 72-74), s nalazišta na prostoru Hrvatske nisu poznate. Zanimljiv je jedino nalaz posude pronađene na položaju vinograd Streim na Vučedolu koja svojim izgledom neodoljivo podsjeća na antropomorfne, viseće posude, jedino što umjesto stiliziranih ruku ima dvije velike lažne ručke čvrsto

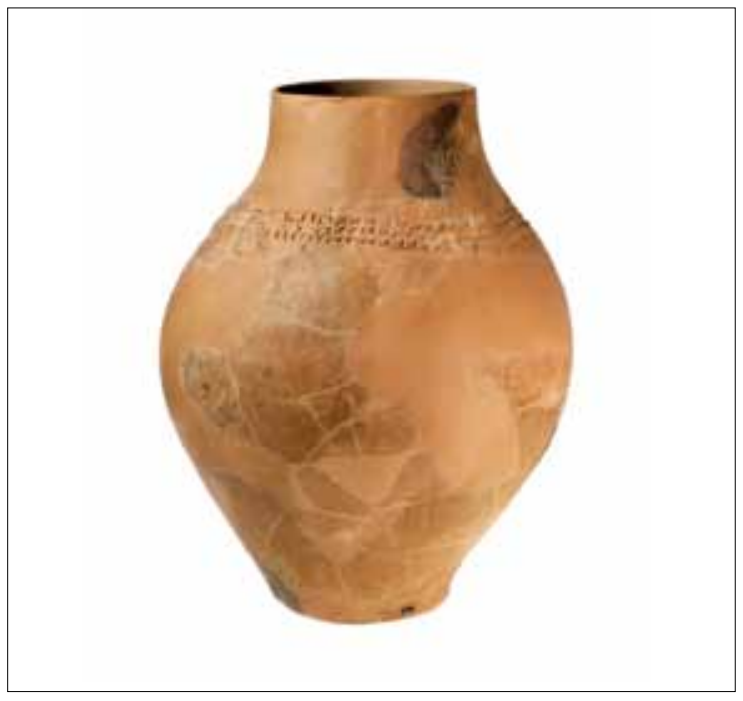

Slika / Figure 4. Lonac s lokaliteta Đakovo-Štrosmajerovac-Pustara / A pot from the site of Đakovo-Štrosmajerovac-Pustara (foto / photo: I. Krajcar)

out a head (discovered in settlements), anthropomorphic vessels, i.e. vessels with stylized depictions of hands, and finds of tombstones - square limestone pillars that are $240 \mathrm{~cm}$ tall and weigh about 600 kg (Endrődi 2003: 410; Endrődi 2004: 2734). Only four figurines without a head have been discovered in Croatia: two at Vučedol (Težak-Gregl 1988), and one each at Aljmaš (Šimić 2001: 73) and Beli Manastir - the Popova zemlja position (Fig. 6) (Los 2016). Parts of a model depicting a wagon were found at Vučedol in addition to the figurines (TežakGregl 1988: 13), and the site also yielded another two types of figurines: flat ones with incisions filled with stabs (Schmidt 1945: PI. 29:1), and cylindrical ones that were roughly made and have the motif of intersecting ribbons at the bust (Težak-Gregl 1988: 13, note 13). A fragment of a coarse, trapezoidal and undecorated figurine was discovered at Veliko polje (Čataj 2009: 118-119), and an additional figurine was found at Grabrovac near Đakovo (Hršak 2010: 22).

The type of vessel with stylized hands that often appears in Hungary, and was also found at Gomolava in the neighboring Vojvodina (Petrović \& Jovanović 2002: 72-74), is, so far, missing from Croatian sites. A noteworthy find is a vessel discovered at the $\mathrm{Vi}$ nograd Streim position at Vučedol, and which is irresistibly similar to anthropomorphic hanging vessels. However, instead of arms, it has two large false handles that are firmly connected to the amphora body. The holes on the transition of the neck and body suggest that the vessel was probably hung (Težak-Gregl 1998: 125, fig. 46). The author ascribed 


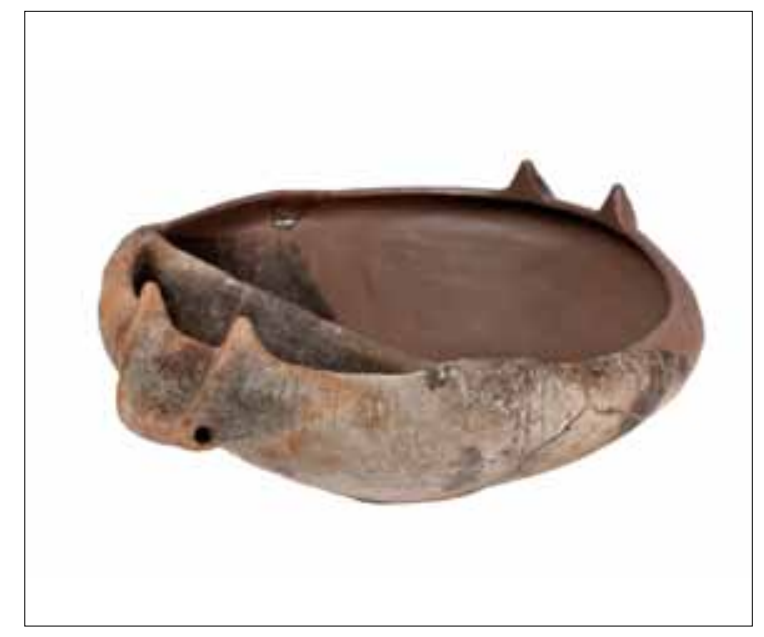

Slika / Figure 5. Posuda s unutarnjom pregradom s lokaliteta Ruščica-Glogove-Praulje / A Vessel with an inner divided from the site of Ruščica-Glogove-Praulje (foto / photo: I. Krajcar).

sraštene s tijelom amfore. Rupice na spoju vrata i trbuha sugeriraju da se vjerojatno posuda vješala (Težak-Gregl 1998: 125, sl. 46). Autorica posudu pripisuje kasnoj badenskoj kulturi, ali ima i tumačenja da je ona vučedolske provenijencije (Durman 1991: 152) iako slični primjerci nisu dosad pronalaženi u okviru vučedolske kulture.

lako se isprva smatralo da je badenska kultura jedna od najsiromašnijih panonskih kultura u odnosu na metalne proizvode (Dimitrijević 1979: 220), nalazi jednodijelnih kalupa, posuda za lijevanje te plosnatih sjekira iz naselja Saloš u Donjoj Vrbi sasvim su promijenili sliku o badenskoj metalurgiji (SI. 7). Osim plosnatih sjekira kakve nalazimo u Sotinu, Oroliku, Boboti, Kutjevu, Sarvašu (Durman 2000: 91-92; Durman 2006: kat. br. 9-18; Ložnjak Dizdar \&

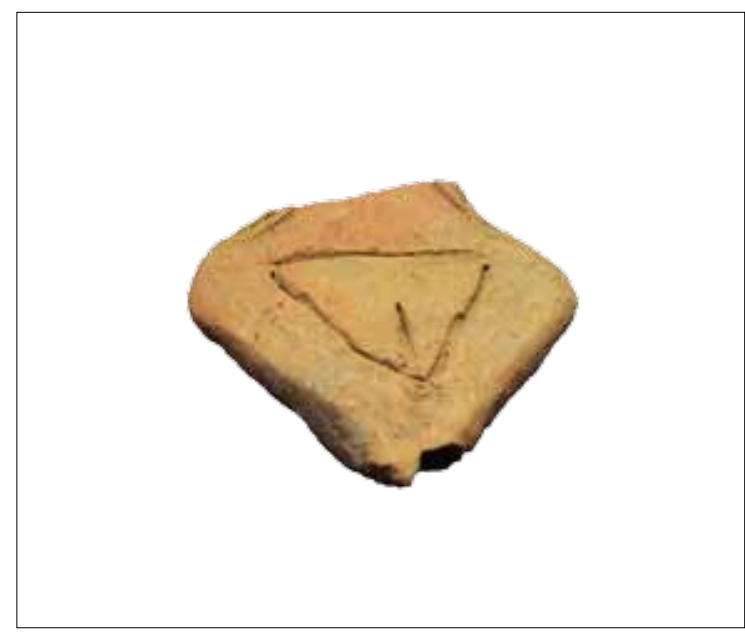

Slika / Figure 6. Ulomak keramičke figure s nalazišta Popova zemlja / A fragment of a ceramic figurine from the site of Popova zemlja (prema / after: Los 2016).

this vessel to the late Baden, but some interpretations ascribe it to the Vučedol culture (Durman 1991: 152), despite the fact that no similar objects were discovered in the context of the Vučedol culture.

Although it was at first thought that the Baden culture was one of the poorest Pannonian cultures when it came to metal finds (Dimitrijević 1979: 220), the discovery of one-piece molds, vessels used in casting and flat axes from the settlement at Saloš in Donja Vrba have completely changed the view of Baden metallurgy (Fig. 7). Other than flat axes, which have been discovered in Sotin, Orolik, Bobota, Kutjevo, and Sarvaš (Durman 2000: 91-92; Durman 2006: cat. no. 9-18; Ložnjak Dizdar \& Dizdar 2015: fig. 3), Vučedol and Sarvaš also yielded awls

Slika / Figure 7. Glineni jednodijelni kalupi za lijevanje bakrenih plosnatih sjekira s nalazišta Saloš u Donjoj Vrbi i Đakovo-Štrosmajerovac-Pustara / A clay one-piece mold for casting flat copper axes from the site of Saloš in Donja Vrba and Đakovo-Štrosmajerovac-Pustara (foto / photo: I. Krajcar). 
Dizdar 2015: sl. 3), poznata su i šila te mali trijangularni bodeži iz Vučedola i Sarvaša (Težak-Gregl 1987; Balen 2005: 56, kat. br. 229). Posude i kalupi za lijevanje osim u Salošu pronađeni su i u Okuklju u Gornjoj Bebrini (Petrović \& Belić 1971:12), te na lokalitetima Ruščica-Glogove-Praulje i Ruščica-Praulje (Bednjanec 2012a; 2012b; Mihaljević et al. 2018). Mišljenja smo da bi primjerak iz Velikog polja mogao biti kalup, a ne, kao što je objavljeno, posuda za lijevanje (Čataj 2009: 121, T.7:1).

\section{Privreda}

U badensko je vrijeme stočarstvo bilo najvažnija gospodarska grana. Goveda su korištena za prehranu, ali ne smijemo isključiti ni njihovu namjenu za rad jer je upravo badenska populacija ta koja je u Europu uvela zaprežna kola na 4 kotača kakve vidimo i na modelima kola.

Dok je za neolitik tipična strategija miješanog gospodarstva, veliki broj kostiju odraslih ženki u eneolitiku pokazatelj je strategije povećanja stada, a time i mesa za prehranu i mlijeka za izradu mliječnih proizvoda (Craig 2002: 99).

Kemijske analize na keramičkom materijalu grupe Boleraz pokazale su na nekoliko tipova posuđa (bikonična zdjela izvijena vrata, vrč s jednom ručkom i amfora/lonac sužena otvora s dvije ručke) da su korišteni u proizvodnji ili čuvanju mlijeka što potvrđuje Sherattovu tezu o jedinstvenoj poljoprivredno-stočarskoj ekonomiji kasnoga eneolitika utemeljenoj na iskorištavanju sekundarnih životinjskih proizvoda (Craig et al. 2003).

$\mathrm{S}$ badenskom se kulturom u Europi najviše povezuje i pojava alkoholnih pića jer su u naseljima i grobovima te kulture često pronalaženi setovi vrčeva i šalica. Keramički setovi za piće iz badenske kulture nalikuju cijelom kompleksu sličnih, ali metalnih, posuda za piće s prostora Anatolije i Egeide (Sheratt 1997: 178, 380-382; Milićević Bradač 1999-2000: 67). S obzirom na kontekst pronađenih setova u sklopu badenske kulture moramo razlikovati one za osobnu uporabu (par šalica) te one korištene u određenim događanjima u kojima sudjeluje čitava zajednica ili povlaštena grupa unutar zajednice (Spasić 2010: 82-94). Njihova prisutnost u grobovima kao prilog pokojniku ili, što je zanimljivije, zasebno ukopavanje setova za piće daje nam naslutiti važnost koja im se pridavala. Pojava setova za piće pada u vrijeme naglih socijalnih, kulturoloških i ekonomskih promjena koje su za- and small triangular daggers (Težak-Gregl 1987; Balen 2005: 56, cat. no. 229). Other than in Saloš, casting vessels and molds were also found at Okukalj in Gornja Bebrina (Petrović \& Belić 1971:12), as well as at the sites of Ruščica-Glogove-Praulje and Ruščica-Praulje (Bednjanec 2012a; 2012b; Mihaljević et al. 2018). The author is of the opinion that the find from Veliko polje could be a mold and not, as reported, a casting vessel (Čataj 2009: 121, PI. 7:1).

\section{Economy}

During the Baden culture, animal husbandry was the most important branch of economy. Cattle was used in the diet, but it might have also been used for work, because it was precisely the Baden populations who introduced wagons on four wheels into Europe, exactly like those represented on models.

While a mixed economy is typical of the Neolithic, the large number of remains of grown female animals in the Eneolithic indicates the strategy of increasing a herd, thereby also the amount of meat in the diet and the amount of milk available for making dairy products (Craig 2002: 99).

Chemical analyses of pottery of the Boleraz group revealed traces of producing or storing milk in several vessel types (biconical bowls with an inverted neck, jugs with one handle, and amphoras/pots with a narrow opening and two handles), thereby confirming Sheratt's hypothesis of a single agricultural and livestock economy of the Late Eneolithic that was based on the use of secondary animal products (Craig et al. 2003).

In Europe, the Baden culture is most often connected to the appearance of alcoholic drinks, because settlements and graves ascribed to this culture yielded sets composed of jugs and cups. Ceramic drinking sets of the Baden culture resemble a whole line of similar, but metal, drinking vessels from Anatolia and the Aegean (Sheratt 1997: 178, 380-382; Milićević Bradač 1999-2000: 67). Considering the context of the recovered sets of the Baden culture, it is necessary to differentiate between those for personal use (a pair of cups), and those used at certain events that included the entire community or a privileged group within the community (Spasić 2010: 82-94). Their presence in graves as grave goods or, even more interestingly, the separate burials of drinking sets, reveal the value that was ascribed to them. The appearance of drinking sets happened 
desile ovaj dio Europe pojavom badenske kulture. Napredak metalurgije, upotreba kola i pojava konja povlače sa sobom i izdvajanje društvene elite (Sheratt 1997: 385-388).

Analiza ostataka faune badenskog sloja na Vučedolu pokazuje da su najčešće kosti bovida, druge po učestalosti su kosti svinja, a tek treće malih preživača (ovce i koze) (Jurišić 1988: 18-25; Kužir 2002). Uzgajanje stoke sitna zuba imalo je perifernu ulogu što možemo vidjeti i na analizi faune $s$ badenskih lokaliteta u Mađarskoj na kojima je također ustanovljeno da je karakteristika ekonomije držanje goveda, iako su prisutne i ovce, koze i svinje (Endrődi 2004: 15).

Konkretne dokaze sekundarne upotrebe životinja nažalost nemamo, osim nekih tragova na kostima goveda koji sugeriraju da su korištena za vuču (Trbojević Vukičević 2006). Također, na materijalu iz Vučedola vidljiva je dominacija kostiju ženskih primjeraka nad muškima, što, kao što smo već naglasili, sugerira strategiju povećanja stada radi mesa i mliječnih proizvoda, kao i veći broj jedinki srednje životne dobi što bi nam također sugeriralo da goveda nisu korištena isključivo radi mesa.

Miješano poljodjelsko-stočarsko gospodarstvo potvrđuje i veliki broj žitarica ustanovljenih na badenskim nalazištima u Mađarskoj: pšenica, ječam, leća, grašak. Dosta nalaza žirova hrasta pokazuje i njihovo korištenje u prehrani (Endrődi \& Gyulai 1998/2000: 29-33; Gyulai 2004: 21-24)

Na primjeru lokaliteta Vučedol vidi se da su u prehrani znatnu ulogu imale i ribe: u prvome redu šarani, zatim som i štuka te su u većem broju zastupljeni školjkaši (Paunović \& Lajtner 1995).

Istraživanja nekoliko nalazišta u blizini Slavonskoga Broda potvrdila su da su nosioci badenske kulture bili izvrsni metalurzi te da su koristili sulfidni bakar (arsensku broncu) za izradu oruđa i oružja (bodeži, noževi, plosnate sjekire). at a time of sudden social, cultural and economic changes that were happening in this part of Europe when the Baden culture was forming. Advances in metallurgy, the use of wagons and the introduction of horses resulted in the emergence of social elites (Sheratt 1997: 385-388).

Analyses of faunal remains from the Baden layer at Vučedol show that bovids are dominant, followed by pigs, and small ruminants (sheep and goats (Jurišić 1988: 18-25; Kužir 2002). The breeding of small animals had a peripheral role, as can be seen from the analysis of fauna from sites of the Baden culture in Hungary, which also show that the main characteristic of the economy was cattle breeding, although sheep, goats and pigs were recorded (Endrődi 2004: 15).

Clear evidence of the secondary use of animals is, unfortunately, lacking, other than some traces on cattle bones that suggest the animals were used for hauling (Trbojević Vukičević 2006). Similarly, the material from Vučedol reveals a prevalence of female over male animals, which, as noted above, suggests the strategy of increasing the herd in order to obtain meat and dairy products. It also revealed a large number of older animals, suggesting that cattle were not only kept for procuring meat.

The mixed economy based on agriculture and animal husbandry is also attested to by the large number of grains discovered at sites of the Baden culture in Hungary: wheat, barley, lentils, and peas. Numerous finds of acorns suggest that they too were used in the diet (Endrődi \& Gyulai 1998/2000: 29-33; Gyulai 2004: 21-24)

The example of Vučedol shows that fish also played an important role in the diet: primarily carp, followed by catfish and pike, as well as numerous shellfish (Paunović \& Lajtner 1995).

Excavations of several sites near Slavonski Brod confirmed that the carriers of the Baden culture were excellent metallurgists and that they used sulfide copper (arsenic bronze) to produce tools and weapons (daggers, knives, flat axes). 


\section{Literatura / Bibliography}

Bakić-Stojsavljević, M. 2010, Gornji Slatnik-Grabrovac, Hrvatski arheološki godišnjak 6/2009, 78-79.

Balen, J. 2002, Topografija nalazišta kostolačke kulture u sjevernoj Hrvatskoj, Vjesnik Arheološkog muzeja u Zagrebu 3.s. XXXV, Zagreb, 35-52.

Balen, J. 2004, Izvještaj s četvrte sezone sustavnog arheološkog iskopavanja tela Vučedol, Obavijesti Hrvatskog arheološkog društva XXXVI/3, Zagreb, 63-67.

Balen, J. 2005, Sarvaš - neolitičko i eneolitičko naselje, Musei Archaeologici Zagrebiensis Catalogi et Monographiae Vol. II, Zagreb.

Balen, J. 2006, Vučedol - vinograd Streim, Hrvatski arheološki godišnjak 2/2005, Zagreb, 43-45.

Balen, J. 2010, Eneolitičke kulture na prostoru istočne Hrvatske, Doktorska disertacija, Sveučilište u Zagrebu.

Balen, J. 2016, The Development of Eneolithic Cultures Between the Sava and the Drava Rivers, in: D. Davison, V. Gaffney, P. Miracle \& J. Sofaer (eds), Croatia at the Crossroads, Arheopress, Oxford, 59-73.

Balen, J. 2018, Eneolitičke kulture na prostoru istočne Hrvatske, Arheologija na Dunavu, Izdanja Hrvatskog arheološkog društva 31/2017, 65-74.

Balen, J. \& Drnić, I. 2014, Arheološka istraživanja na lokalitetu Barbarsko - novi prilog poznavanju srednjeg eneolitika na prostoru sjeverne Hrvatske, Vjesnik arheološkog muzeja u Zagrebu XLVII, 39-76.

Bankoff, H. A. \& Winter, F. A. 1990, The Later Aeneolithic in Southeastern Europe, American Journal of Archaeology 94, 175-191.

Banner, J. \& Bognár-Kutzián, I. 1961, Beitrage zur Chronologie der Kupferzeit des Karpatenbeckens, Acta Archaeologica Academiae Scientiarum Hungaricae XIII/1-4, Budapest, 1-32.

Bednjanec, L. 2012a, Slavonski Brod - luka (lokalitet Ruščica - Glogove - Praulje, Hrvatski arheološki godišnjak 8/2011, 126-130.

Bednjanec, L. 2012b, Slavonski Brod - luka (lok. Ruščica -Praulje), Hrvatski arheološki godišnjak 8/2011, 130-132.

Bekić, L. 2006, Zaštitna arheologija u okolici Varaždina - Arheološka istraživanja na autocesti ZagrebGoričan i njezinim prilaznim cestama, Zagreb, Hrvatski restaurarski zavod.

Craig O. E. 2002, The development of dairying in Europe: potential evidence from food residues on ceramics, Documenta Praehistorica XXIX, Ljubljana, 97-108.
Craig O. E., Chapman, J., Figler, A., Patay, P., Taylor, G., Collins, M. 2003, Milk Jugs and other myths of the Copper age of Central Europe, European Journal of Archaeology 6/3, 251-265.

Čataj 2009, Badenska kultura, in: L. Čataj (ed.), Josipovac Punitovački - Veliko Polje I, zaštitna arheološka istraživanja na trasi autoceste A5. Eneolitičko, brončanodobno i srednjovjekovno naselje, Zagreb, Hrvatski restauratorski zavod, 105-139.

Čataj, L. 2016, Lasinja, Retz-Gajary and Boleráz? Radiocarbon dates and the sequence of Copper Age Cultures in Central Croatia, in: J. Kovárnik (ed.), Centenary of Jaroslav Palliardi's Neolithic and Aeneolithic Relative Chronology (1914-2014), Philosophical Faculty, University of Hradec Králové, Hradec Králové-Ústí nad Orlicí, 181-192.

Dimitrijević, S 1962, Prilog stupnjevanju badenske kulture u sjevernoj Jugoslaviji. Arheološki radovi $i$ rasprave II, Zagreb, 239-261.

Dimitrijević, S 1968, Sopotsko-lenđelska kultura, Zagreb.

Dimitrijević, S. 1979, Badenska kultura, in: A. Benac (ed.), Prapovijest jugoslovenskih zemalja III, „Svjetlost", OOUR Izdavačka djelatnost, Akademija nauka i umjetnosti Bosne i Hercegovine, Sarajevo, 183234.

Durman, A. 1984, Vučedol 1984 - novi početak sustavnih istraživanja, Obavijesti Hrvatskog arheološkog društva 3, Zagreb, 34-38.

Durman, A. 1987, "Vinograd Streim" - četvrta sezona na Vučedolu, Obavijesti Hrvatskog arheološkog društva 3, Zagreb, 34-36.

Durman, A. 1991, Metal u prethistorijskom društvu jugoistočne Evrope, Doktorska dizertacija, Sveučilište u Zagrebu, Zagreb.

Durman, A. 2000, Počeci metalurgije na brodskom području, Zbornik radova sa znansvenog skupa o Slavonskom Brodu u povodu 750. obljetnice prvoga pisanog spomena imena Brod, Slavonski Brod, 91-102.

Durman, A. 2006, Simbol boga i kralja - prvi europski vladari, Katalog izložbe, Zagreb.

Durman, A. \& Balen, J. 2005, Vučedol - vinograd Streim, Hrvatski arheološki godišnjak 1/2004, Zagreb, 30-33.

Endrődi A. 2003, Ein neues spätkupferzeitliches Idolbruchstück aus Budapest. Gedanken über die Erscheinungen des religiösen Lebens, in: E. Jerem \& P. Raczky (eds.), Morgenrot der Kulturen, Frühe Etappen der Menschheitsgeschichte in Mittel- und Südosteuropa, Festschrift für Nándor Kalicz zum 75. Geburtstag, Archaeolingua, Budapest, 401-414. 
Endrődi A. 2004, Everyday life and spirituality at the end of the Copper Age - 5000 years old remains of the Baden Culture in Budapest, Budapest.

Endrődi A. \& Gyulai F. 1998/2000, Hearths and other finds of the Late Copper Age Baden Culture at Budapest-Csepel Island (Gynaecomorphic vessels, archaeobotanical remains), Archaeologiai Értesitő 125, 9-44.

Foltiny, S. \& Ohrenberger, A. 1952, Neue Funde aus dem Bezirk neusiedel am See, Archaeologia Austriaca IX, Wien.

Forenbaher, S. 1993, Radicarbon dates and absolute chronology of of the central European Early Bronze Age, Antiquity, vol. 67, No 255, 218-220, 235-256.

Gyulai F. 2004, Plants of the Baden culture, in: A. Endrödi (ed.), Everyday life and spirituality at the end of the Copper Age - 5000 years old remains of the Baden Culture in Budapest, Budapest, 21-26.

Horváth, T., Gherdán, K., Herbich, K., Vasáros, Zs. 2007, Häuser der Badener Kultur am Fundort Balatonőszöd Temetői dűlő, Archaologische Untersuchungen. Acta Archaeologica Academiae Scientiarum Hungaricae LVIII/1, Budapest, 43-105.

Horváth, T., Svingor, S. E., Molnár, M. 2008, New radiocarbon dates for the baden culture, Radicarbon 50/3, 447-458.

Horváth, T. 2004, A new human representation from the Baden culture: a mask from Balatonőszöd, Acta Archaeologica Academiae Scientiarum Hungaricae LV/3-4, Budapest, 179-237.

Horvath, T. 2012, Networks and Netwars: new perspectives on the Late Copper Age and Early Bronze Age. Typo-chronological relationships of the Bole$\mathrm{raz}$ Baden/Kostolac finds at the site of Balatonőszod-Temetői dűlö, Hungary, British Archaeological Reports International Series 2427, Oxford.

Horvatinčić, N., Obelić, B., Srdoč, D., Durman, A., Benko, L., Sliepčević, A. 1990, Radiocarbon and TL Dating of the Eneolithic Site Vučedol in East Croatia, Yugoslavia, PACT 29, 243-250.

Hršak, T. \& Bojčić, Z. 2008, Štrosmajerovac - Pustara. Hrvatski arheološki godišnjak 4/2007, Zagreb, 41-43.

Hršak, T. 2010, Grabrovac-Ciglana, Hrvatski arheološki godišnjak 6/2009, Zagreb, 21-23.

Janković, I. \& Novak, M. 2018, Bioarheologija bakrenodobnih populacija na tlu kontinentalne Hrvatske, in: J. Balen, I. Miloglav \& D. Rajković (eds.), Povratak u prošlost - Bakreno doba u sjevernoj Hrvatskoj, Zagreb, 211-223.

Jurišić, M. 1988, Lov i stočarstvo vučedolskog kulturnog kompleksa u sjevernim dijelovima Jugoslavije, Magistarski rad, Zagreb, 1988.
Jurišić, M. 1990, Ukopi životinja na Vučedolu, Opuscula archaeologica 14, Zagreb, 17-31.

Jurković, T. 2012, Velimirovac-Arenda 1, Hrvatski arheološki godišnjak 8/2011, 46-49.

Kalafatić, H., 2009, Zaštitna istraživanja lokaliteta Čepinski Martinci - Dubrava na trasi autoceste Beli Manastir - Osijek - Svilaj 2007. i 2008, Annales Instituti archaeologici 5, Zagreb, 20-26.

Kalicz, N. 1963, Die Péceler (Badener) Kultur und Anatolien, Studia archaeologica II, Budapest.

Kalicz, N. 2001, Die Protoboleráz-Phase an der Grenze von zwei Epochen. in: P. Roman \& S. Diamandi (eds.), Studia Danubiana. Series Symposia II. Symposium Cernavoda III - Boleráz, București, 385-435.

Kužir, S. 2002, Arheozoološko istraživanje kostiju i zubiju životinja badenske kulture s lokaliteta Vučedol, Magistarski rad, Veterinarski fakultet, Zagreb.

Los, Dž. 2016, Lokalitet AN2 Beli Manastir-Popova zemlja, izložba Tekuća arheološka istraživanja, Arheološki muzej u Zagrebu.

Lozuk, J. 2006, Saloš kraj Donje Vrbe, in: A. Durman (ed.), Stotinu hrvatskih arheoloških nalazišta, Leksikografski zavod Miroslav Krleža, Zagreb 2006, 228229.

Ložnjak Dizdar D., Hutinec M., Dizdar M. 2014, Terenski pregled područja između Sotina i Opatovca, Annales Instituti Archaeologici X, Zagreb, 159-163.

Ložnjak Dizdar D. \& Dizdar M. 2015, Sotin i Opatovac, probna arheološka istraživanja višeslojnih nalazišta 2014. godine, Annales Instituti Archaeologici XI, Zagreb, 9-13.

Ložnjak Dizdar, D., Dizdar M., Tonc A. 2016, Donji Miholjac - Panjik - zaštitno istraživanje naselja sopotske i badenske kulture u Podravini, Annales Instituti Archaeologici XII, Zagreb, 59-62.

Maran, J. 1998, Die Badener Kultur und der ägäischanatolische Bereich, Germania 76/2, 497-525.

Marković, Z. 1977, Problem eneolita u našičkoj regiji, Arheološki vesnik 27/1976, Ljubljana, 42-59.

Marković, Z. 1994, Sjeverna Hrvatska od neolita do brončanog doba, Koprivnica.

Mihaljević, M. 2010, Vidovci-Rosulje, Hrvatski arheološki godišnjak 6/2009, 116-117.

Mihaljević, M., Podunavac, D., Matković Vrban, M. 2018, Zaštitna arheološka istraživanja Ruščica Glogove Praulje, Nova Gradiška, katalog izložbe

Mihelić, S. 2008, Josipovac - Gravinjak. Hrvatski arheološki godišnjak 4/2007, Zagreb, 15-17.

Milićević Bradač, M. 1999-2000, BRÓMOS OU BRÓMIOS - Bromo, a ne Bromije (Anth. Pal. 9. 368), Opuscula archaeologica 23-24, Zagreb, 65-76. 
Milojčić, V. 1949, Chronologie der jungen Steinzeit Mittel- und Sudeuropas, Berlin.

Milojčić, V. 1959, Zur Chronologie der jüngeren Stein- und Bronzezeit Südost- und Mitteleuropas, Germania 37/1-4.

Miloglav, I. 2016, Keramika u arheologiji - Iončarstvo vučedolske kulture na vinkovačkom području, Acta Musei Cibalensis 7, Gradski muzej Vinkovci, Filozofski fakultet Sveučilišta u Zagrebu, Vinkovci-Zagreb. Němejcová-Pavúková, V. 1981, Náčrt periodizácie badenskej kultúry a jej chronologickýchodnej Európe, Slovenská Archeológia XXIX/2, Bratislava, 261296.

Němejcová-Pavúková, V. 1991, Typologische Fragen der relativen und absoluten chronologie der Badener Kultur, Slovenská Archeológia XXXIX/1-2, Bratislava, 59-90.

Neustupný, E. 1959, Zur Entstehung der Kultur mit kanneliert Keramik, Slovenská Archeológia VII/2, Bratislava, 260-284.

Nikitović, D., Janković, I., Mihelić, S. 2012, Juvenile elbow dislocation from the prehistoric site of Josipovac - Gravinjak, Croatia, International Journal of Paleopathology 2, 36-41.

Nikolić, D. 2000, Kostolačka kultura na teritoriju Srbije, Beograd.

Nodilo, H. 2012, Donji Miholjac-Mlaka, Hrvatski arheološki godišnjak 8/2011, 12-15.

Paskojević, K. 2011, Velika Londžica - Malo Polje, Hrvatski arheološki godišnjak 7/2010, 65-67

Paunović, M. \& Lajtner, I. 1995, Bedeutung der MoIlusken- und Fischfauna in der Ökologie und Ökonomie der Äneolitischen siedlung Vučedol (NO Kroatien), Opuscula archaeologica 19, Zagreb, 33-38.

Pavlović, I. 1984, Rezultati arheoloških iskopavanja na lokalitetu Grabrovac u god. 1980, Arheološka istraživanja u istočnoj Slavoniji i Baranji, Izdanja Hrvatskog arheološkog društva 9/1981, Zagreb, 53-61.

Petrović, K. \& Belić, B. B. 1971, Praistorijske kulture na području brodskog posavlja, Materijali VII, Beograd, 9-20.

Petrović, J. \& Jovanović, B. 2002, Gomolava - naselja kasnog eneolita, Novi Sad - Beograd.

Pittioni, R. 1954, Urgeschichte des österreichisches Raum, Wien.

Rajković, D. \& Balen, J. 2016, Sarvaš - Neolitičko $i$ eneolitičko naselje II, Muzej Slavonije, Arheološki muzej u Zagrebu, Osijek.
Schmidt, R. R. 1945, Die Burg Vučedol, Zagreb.

Sheratt, A. 1997, Economy and society in Prehistoric Europe, Edinburgh.

Spasić, M. 2010, Prva zdravica, Muzej grada Beograda.

Stadler, P., Draxler, S., Friesinger, H., Kutschera, W., Priller, A., Rom, W., Steirer, P., Wild, E.M. 2001, Absolute Chronology for Early Civilisations in Austria and Central Europe using 14C Dating with Accelerator Mass Spectrometry with special Results for the Absolute Chronology of the Baden Culture, in: $P$. Roman \& S. Diamandi (eds.), Studia Danubiana. Series Symposia II. Symposium Cernavoda III - Boleráz, București, 541-562.

Šimić, J. 1998, Istraživanje lokaliteta Retfala u Osijeku, kasnobrončano doba istočne Slavonije, Izdanja Hrvatskog arheološkog društva 19, Zagreb, 235-242.

Šimić, J. 2001, Aljmaš - Podunavlje, zaštitno istraživanje višeslojnog prapovijesnog nalazišta, Obavijesti Hrvatskog arheološkog društva 3, Zagreb, 70-75.

Šimić, J. 2005, Retfala, Hrvatski arheološki godišnjak 1/2004, Zagreb, 11-12.

Šimić, J. 2006, Aljmaš - Podunavlje, Hrvatski arheološki godišnjak 2/2005, Zagreb, 7-8.

Tasić, N. 1967, Badenski i vučedolski kulturni kompleks u Jugoslaviji, Beograd - Novi Sad.

Tasić, N. 1979, Kostolačka kultura, in: A. Benac (ed.), Prapovijest jugoslovenskih zemalja III, "Svjetlost“, OOUR Izdavačka djelatnost, Akademija nauka i umjetnosti Bosne i Hercegovine, Sarajevo, 235-266.

Tasić, N. 1982-1983, Das probleme der sukzessiven migration wahrend des aneolithikums im Karpaten-Donautal-Balkan-Gebiet, Archaeologia Iugoslavica XXII-XXIII, Beograd, 15-20.

Težak-Gregl, T. 1985, Dva nova groba badenske kulture s Vučedola, Opuscula archaeologica 10, Zagreb, 23-39.

Težak-Gregl, T. 1986, Vučedol kod Vukovara - eneolitsko naselje, Arheološki pregled 26/1985, Ljubljana, 57-59.

Težak-Gregl, T. 1987, Prilog poznavanju metalne produkcije badenske kulture, Opuscula archaeologica 11-12, Zagreb, 73-81.

Težak-Gregl, T. 1988, O problemu idoloplastike u badenskoj kulturi, Opuscula archaeologica 13, Zagreb, 11-21.

Težak-Gregl, T. 1998, Neolitik i eneolitik, in M. Mirić (ed.), Prapovijest, Zagreb, 56-157. 
Tkalčec, T. 2016. Prapovijesna, rimska i srednjovjekovna naselja na lokalitetu Donji Miholjac - Đanovci - zaštitna arheološka istraživanja u 2015. godini, Annales Instituti Archaeologici XII, Zagreb, 46-58.

Trbojević Vukičević, T. 2006, Arheozoološko i tafonomsko istraživanje eneolitičkog goveda Vučedola, Doktorska disertacija, Sveučilište u Zagrebu.

Velušček, A. 2009, Koliščarska naselbina Stare Gmajne in njen čas, Ljubljansko barje $v 2$. polovici 4. tisočletja pr. Kr., Opera Instituti Archaeologici Sloveniae 16, Ljubljana.
Vinski - Gasparini, K. 1956, Iskapanje prethistorijskog naselja u Belom Manastiru, Osječki zbornik V, Osijek, 5-36.

Vodička, K. 2011, Donji Miholjac-Čovci, Hrvatski arheološki godišnjak 7/2010, 15-16

Wild, E.M., Stadler, P., Bondar, M., Draxler, S., Friesinger, H., Kutschera, W., Priller, A., Rom, W., Ruttkay, E., Steier, P. 2001, New Chronological Frame for the Young Neolithic Baden Culture in Central Europe $\left(4^{\text {th }}\right.$ millennium BC), Radiocarbon, 43, 1057-1064. 